\title{
НЕПИНЕЙНАЯ МЕТАППОГЕНИЯ
}

И БОПЬШЕОБЬЕМНОЕ ЗОИОТООРУДЕНЕНИЕ НЕТРАДИЦИОННОГО ТИПА. Ч. ІІ. КЕДРОВСКОЕ ЗОПОТОРУДНОЕ ПРОЯВПЕНИЕ

\section{А. Б. Шепепь, М.Е. Гаврипенко}

Во второй части статьи (первая часть опубликована в № 4 за 2015 г.) для Кедровского большеобъемного проявления золота нетрадиционного типа (Федоровско-Магызы-Калтасская рудоконтролирующая зона) рассмотрены структура рудного поля, строение рудовмещающей толщи и закономерности размещения в ней оруденения. Исследованы вещественный состав, метасоматическая зональность, физико-химические условия формирования, характер распределения редкоземельных элементов, а также изотопов углерода и кислорода в линзо-пластообразных залежах и телах березитоподобных серицит-альбит-анкеритовых метасоматитов, с которыми связано золотое оруденение. Приуроченность Кедровского проявления к глубинному разлому, особенности его вещественного состава и условий формирования позволяют высказать гипотезу об участии интрателлурических флюидов в процессах корового рудогенеза и доминирующей их роли как источников вещества и энергии.

Ключевые слова: нелинейная металлогения, флюидный мантийно-коровый рудогенез, интрателлурические флюиды, Федоровско-Магызы-Калтасская рудоконтролирующая зона, Кедровское большеобъемное золоторудное проявление нетрадиционного типа.

DOI 10.20403/2078-0575-2016-1-71-85

\section{NONLINEAR METALLOGEYY AND BULK GOLD MINERALIZATION}

OF UNCONVENTIONAL TYPE. PT II. KEDROVSKOYE GOLD-ORE OCCURRENCE

\section{A. B. Shepel, M.E. Gavrilenko}

In the second part of the paper (the first one was issued in no. 4, 2015), one of the gold-ore occurrences of the Fedorovsko-Magyzy-Kaltasskaya ore-controlling zone - the large-scale non-conventional Kedrovskoye occurrence - is discussed in terms of the ore-field structure, the structure of ore-hosting formation, and distribution regularities of mineralisation therein. The authors studied the material composition, metasomatic zoning, physical-chemical formation conditions, distribution pattern of rare earth elements as well as carbon and oxygen isotopes in lense- and blanket-form deposits and bodies of beresite-like sericite-albite-ankerite metasomatites, with which the gold mineralisation is associated. The confinement of the Kedrovskoye occurrence to a deep fault, peculiarities of its material composition and formation conditions enable the authors to suggest the involvement of intratelluric fluids in the crustal ore genesis and their prevailing part as a source of matter and energy.

Keywords: non-linear metallogeny, fluid mantle-crustal ore genesis, intratelluric fluids, the FedorovskoMagyzy-Kaltasskaya ore-controlling zone, the large-scale non-conventional Kedrovskoye occurrence.

В связи с сокращением в России рентабельных запасов коренного и россыпного золота, весьма актуальны поиски и освоение крупных золоторудных месторождений с убогими и бедными рудами [12]. Судя по результатам поисковых работ на рудное золото, уже в недалеком будущем перспективы золотодобывающей отрасли в Кузнецком Алатау и Горной Шории могут быть связаны с разработкой большеобъемных месторождений золота нетрадиционного типа [24]. Один из таких объектов - Кедровское золоторудное проявление Кедровско-Федоровского рудного поля Федоровско-Магызы-Калтасской зоны (ФМКЗ). В 2004 г. Кедровское проявление по предложению СНИИГГиМС наряду с Магызинским и Калтасским было включено в федеральный перечень объектов для постановки геолого-разведочных работ на рудное золото. В этих работах, выполненных ОАО «Берег» в 2005-2007 гг. и ООО «СибГео» в 2012-2014 гг. (при научном обеспечении и сопровождении со стороны СНИИГГиМС и ЦНИГРИ), были локализованы, оценены и апробированы прогнозные ресурсы золота по категории $\mathrm{P}_{1}$ в количестве 77 т при среднем содержании 2,5 г/т и бортовом 0,2 г/т [2].

На примере Кедровского проявления Федоровско-Магызы-Калтасской зоны рассмотрим особенности геологического строения большеобъемных золоторудных месторождений нетрадиционного типа $[9,20]$ для обоснования принадлежности Кедровского проявления к классу мантийных месторождений, который выделяется в рамках нелинейной металлогении. Это новое направление в геологии, изучающее закономерности размещения эндогенных месторождений полезных ископаемых [26].

В геологчческом строении Кедровского проявления участвует калтасский зеленосланцевый комплекс раннего рифея, слагающий верхний структурный этаж Томского выступа и представленный метаморфизованными осадочно-вулканогенными отложениями калтасской свиты раннего рифея [21]. По результатам стратиграфического и литолого-пет- 
рографического изучения опорных геологических разрезов вдоль поисковых линий Кедровского участка в составе рудовмещающей толщи калтасского комплекса выделяются три крутопадающие на северо-запад стратиграфически и литологически обособленные пачки (снизу вверх): нижняя, средняя и верхняя (рис. 1). Нижняя метабазитовая пачка (мощность более 1000 м) слагает северозападную часть участка. В ней преимущественно распространены метабазальты и апобазальтовые метаморфические сланцы хлорит-актинолитового, эпидот-хлорит-актинолитового, реже биотит-актинолит-хлорит-эпидотового состава. Средняя метакарбонатная пачка (мощность 250-300 м) сложена мраморизованными графитсодержащими известняками, а верхняя метакарбонатно-терригенная (мощность более 300 м) - хлорит-серицитовыми сланцами по аргиллитам, алевролитам, реже песчаникам с линзами мраморизованных известняков. Породы имеют крутое падение на северо-запад, слагая опрокинутое на юго-восток восточное крыло антиклинальной складки. Рудовмещающая толща содержит согласные и субсогласные тела метагаббро и метагаббро-порфиритов, рассекается дайками долеритов.

По данным реконструкции геодинамических обстановок в формировании вулканогенного протолита рудовмещающей толщи выделяются два этапа: рифтовый и островодужный. Первый представлен вулканитами щелочной серии (щелочные базальты, ультраосновные фоидиты), второй - толеитовой и известково-щелочной (базальты, андезибазальты, андезиты, дациты) [21]. Рифтовый этап связан с глобальным процессом континентального рифтогенеза в начале раннего рифея. В это время в связи с проявлением масштабной плюмтектоники в Алтае-Саянской складчатой области была сформирована крупная (радиусом около 400 км) КузнецкоАлатауско-Саянская кольцевая морфоструктура [25]. В краевой зоне этой морфоструктуры проходит Кузнецко-Алтайский глубинный разлом, представляющий дуплекс растяжения и контролирующий размещение ФМКЗ и ее золоторудных объектов, включая Кедровское проявление.

Геохимическая особенность метавулканитов калтасского рудовмещающего комплеса - повышенная золотоносность. Концентрация золота в них составляет 3,2-6,8 мг/т, иногда достигая 69 мг/т, что в 2-3 раза превышает средний уровень в более молодых вулканических комплексах региона [27]. На Кедровском проявлении в метабазальтах и апобазальтовых метаморфических сланцах нижней пачки калтасского комплекса по данным пробирного анализа содержится 7-15 мг/т золота. В мраморизованных графитсодержащих известняках средней пачки количество золота изменяется следующим образом: из 40 проб в половине менее 5 мг/т золота, а в другой - 7-84 мг/т (данные атомно-абсорбционного анализа). При этом повышенные содержания золота в мраморизованных известняках отмечаются вблизи рудных тел, что, по-видимому, связано с наложенным характером золотоносности. В сланцах по терригенным породам и в мраморизованных известняках верхней пачки золота менее 5 мг/т.

В метагаббро и метагаббро-порфиритах концентрация золота по данным пробирного анализа 5-70 мг/т, а по результатам нейтронно-активационного анализа - 7(18)-83(110) мг/т (определения проводились в навесках 7,0 и 0,2 г, содержания в навеске 0,2 г приведены в скобках).

Поскольку базальты и габбро - продукты плавления мантии, можно допустить, что мантия могла быть источником не только золотоносных магм, но и золотоносных флюидов, принимавших участие во флюидном мантийно-коровом рудогенезе.

Рудоконтролирующими структурами на Кедровском проявлении служили линейные согласные и субсогласные с простиранием рудовмещающей толщи зоны рассланцевания, брекчирования, катаклаза и будинажа шириной 150-200 м и протяженностью 4-8 км. Вдоль них интенсивно выражены процессы гидротермально-метасоматического преобразования вмещающих пород, приведшие к формированию линзо-пластообразных залежей золотоносных метасоматитов, а также золотоносных кварцевых жил и штокверков, секущих метасоматиты.

Рудолокализующими структурами для линзо-пластообразных залежей золотоносных метасоматитов являлись крутопадающие контакты карбонатных и алюмосиликатных магматических пород, обладающих различными физико-химическими и физико-механическими свойствами.

По морфологии и пространственному размещению залежей золотоносных метасоматитов структура Кедровского участка может быть отнесена

\section{Рис. 1. Геолого-поисковый план Кедровского золоторудного проявления}

1-3 - пачки калтасского зеленосланцевого комплекса раннего рифея: 1 - верхняя (метакарбонатно-терригенная) хлорит-серицитовые сланцы по аргиллитам, алевролитам, редко песчаникам с прослоями мраморизованных известняков, 2 - средняя (метакарбонатная) - мраморизованные известняки графитсодержащие, 3 - нижняя (метабазитовая) - метабазальты, метаандезибазальты, метатрахиандезибазальты и эпидот-хлорит-актинолитовые сланцы по базальтам, андезибазальтам и трахиандезибазальтам; 4 - дайки долеритов среднего кембрия; 5 - метагаббро, метагаббропорфириты метаморфизованного субвулканического комплекса раннего рифея; 6 - известняки мраморизованные графитсодержащие; 7 - метабазальты и сланцы эпидот-хлорит-актинолит-альбитовые по базальтам; 8 метагаббро, метагаббро-порфириты; 9 - сланцы серицит-графит-кварцевые; серицит-хлорит-полевошпат-кварцевые графитсодержащие; 10 - метасоматиты хлорит-серицит-анкерит-альбитовые и хлорит-серицит-анкеритовые; 11 - рудные тела; 12 - геологические границы; 13 - канава и ее номер; 14 - скважина и ее номер 


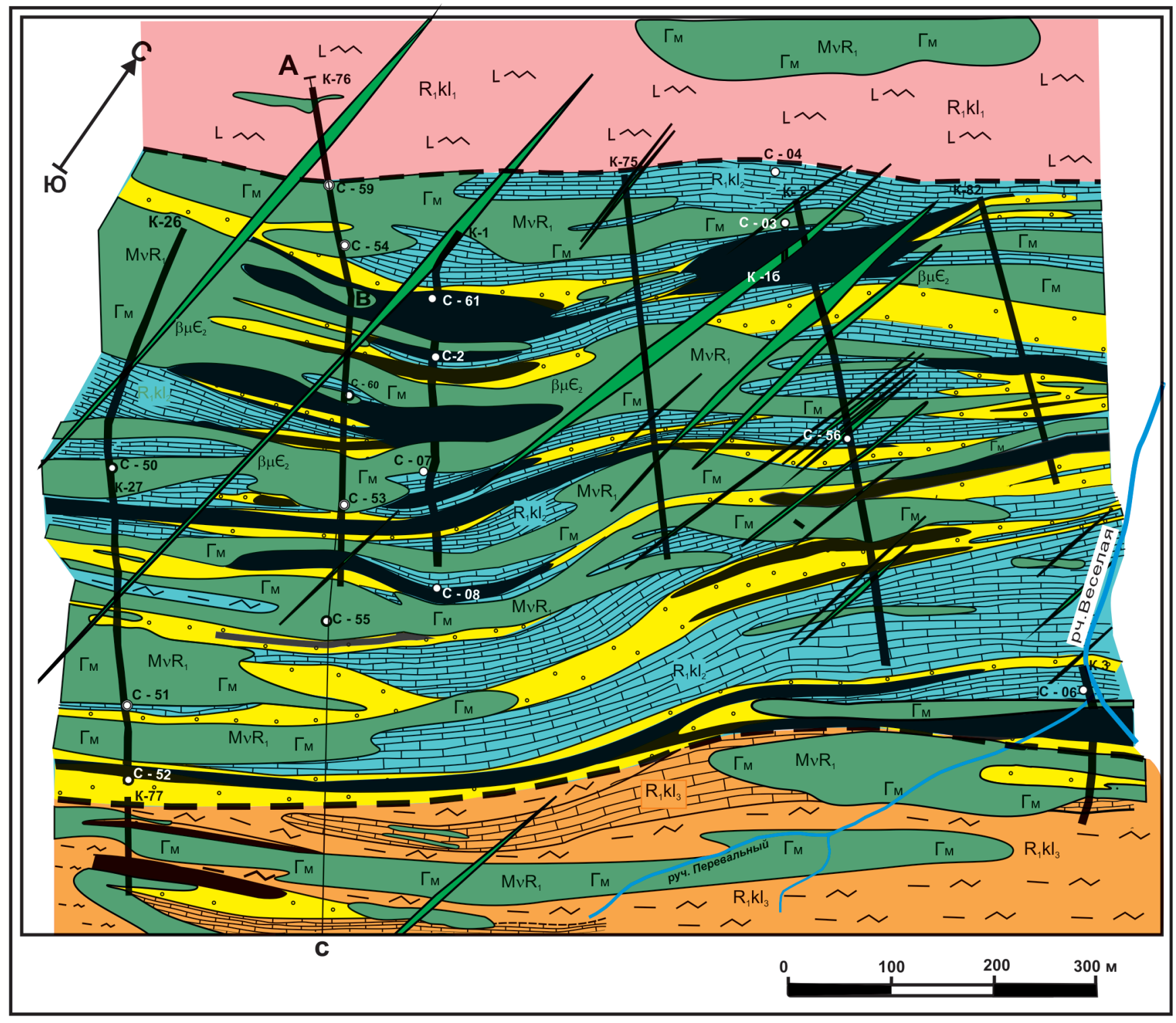

告

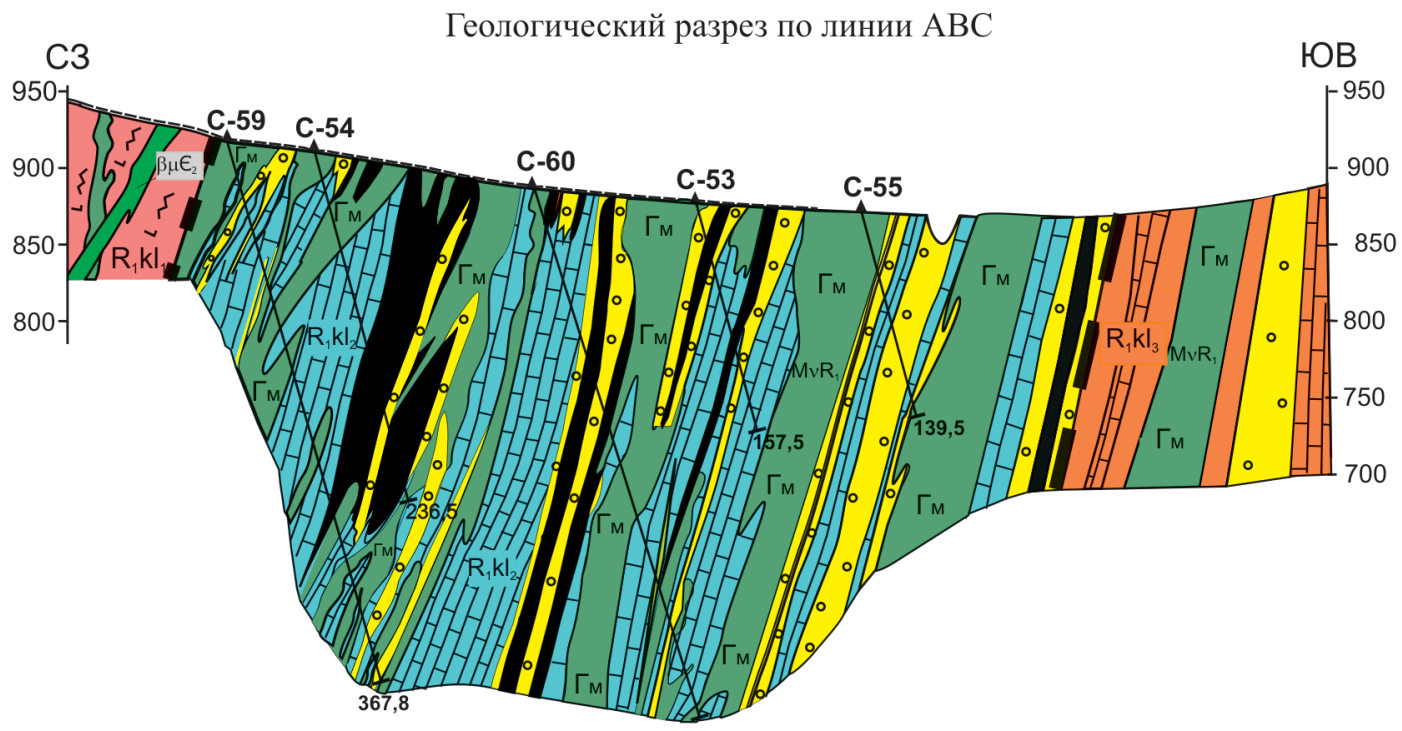

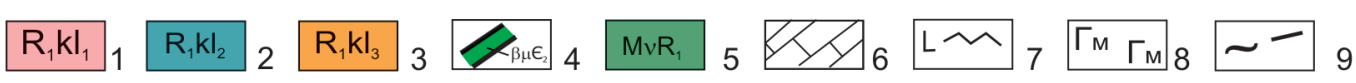

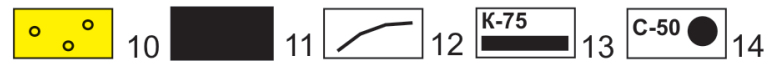


к «плоскому морфологическому типу и планпараллельному структурному подтипу» (по В. Г. Ведерникову [5]). Этот подтип характеризуется системой субпараллельных кулисообразных минерализованных зон, рудных залежей и тел. Определяющее значение в формировании таких рудных полей имеют пликативно-дизъюнктивные дислокации, связанные с крупными разломами фундамента. Основную структуроформирующую роль в пределах Кедровского участка играли пликативные, а не дизъюнктивные дислокации. Об этом свидетельствуют отсутствие секущих рудных тел и специфическая структурно-текстурная особенность метасоматитов - их сланцеватая текстура. Установлено, что подобными текстурными признаками характеризуются синтектонические метасоматиты зон глубинных разломов, где они формируются при стрессе в пластической среде в восстановительных условиях при интенсивном массопереносе флюидами петрогенных и рудных компонентов [19]. При этом метасоматиты либо наследуют сланцеватую текстуру метаморфических пород, либо (в случае изменения плана деформаций) в них формируется своя, иначе ориентированная кристаллизационная сланцеватость.

Таким образом, золотоносные метасоматиты Кедровского проявления, могут быть классифицированы как синтектонические метасоматиты КузнецкоАлтайского глубинного разлома.

Морфология, минеральный состав и зональность рудных тел. Золотоносные синтектонические метасоматиты слагают линзо-пластообразные рудные тела протяженностью 100-1020 м по простиранию и до 270 м по падению при мощности от 1,0 до 59,0 м и среднем значении 13,9 м.

Породообразующими минералами золотоносных метасоматитов являются (об. \%) серицит (ино-

a

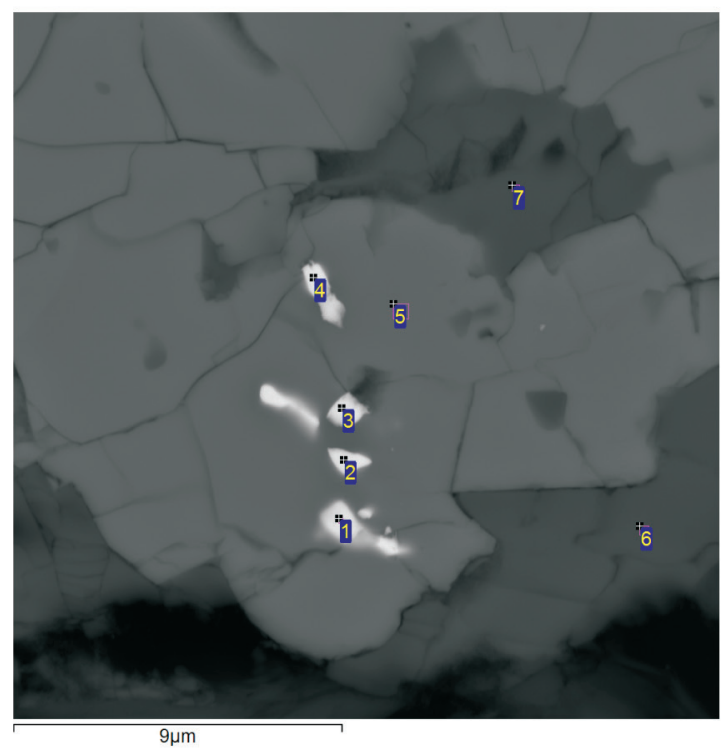

гда парагонит) 10-30, хлорит 5-25, анкерит 25-40, сидерит 0-5, альбит 5-30, кварц 5-7. В качестве типоморфной примеси присутствует углеродистое вещество (<1-5). Акцессории представлены: сфеном (лейкоксеном) 1-2, апатитом <1, ксенотимом $<<1$ и монацитом $<<1$; рудные - сульфидами (от $<1$ до 6-7) - пирит, пирротин, халькопирит, сфалерит, галенит; сульфоарсенидами - кобальтин, герсдорфит, арсенопирит; арсенидами - саффлорит; сульфосолями - блеклая руда (теннантит, тетраэдрит, фрейбергит).

Золото в метасоматитах наблюдалось в виде мелких (размером от 0,001×0,003 до 0,009×0,016 мм) кристаллоподобных (изометрично-полигональных) и изометрично-неправильной формы включений во всех породообразующих минералах метасоматитов - анкерите, сидерите, сериците, альбите, кварце и пирите (рис. 2). Включения могли быть захвачены при близкоодновременной кристаллизации золота и других минералов из рудоносных мантийных флюидов. Это позволяет отнести золото к минеральному парагенезису метасоматитов, предполагая его кристаллизацию на ранней стадии формирования парагенезиса.

Золото в метасоматитах распределено крайне неравномерно: участки размером 0,04×0,06 мм, содержащие вкрапленность золота, перемежаются с безрудными протяженностью в несколько миллиметров. Принимая во внимание синтектоническую природу и сланцеватую текстуру золотоносных метасоматитов и учитывая, что скорость переноса флюидных компонентов по сланцеватости в условиях высоких температур и давлений на несколько порядков превышает скорость диффузионного переноса [16], можно предположить, что неравномерность распределения тонкодисперсного

б

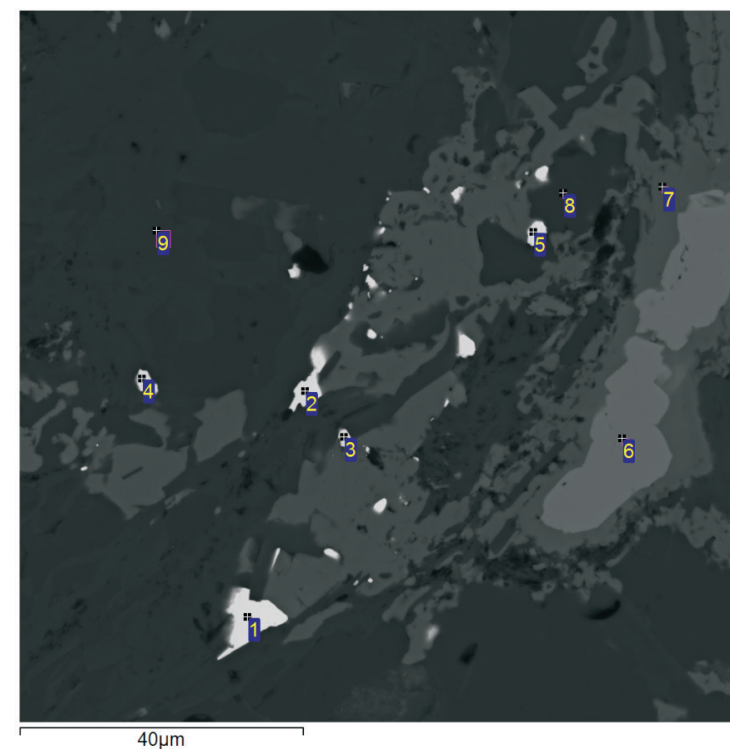

Рис. 2. Включения золота в минералах золотоносных метасоматитов Кедровского проявления (скв. 54, гл. 179,5 м, обр. С-54-179,5): а - 1-4 - золото, 5 - пирит, 6, 7 - сидерит; б - 1-5 - золото, 6 - пирит, 7 - сидерит, 8 - альбит, 9 серицит 
золота могла быть обусловлена турбулентностью флюидного потока. В результате во флюидном потоке возникали многочисленные вихри, из-за чего гидродинамические и термодинамические характеристики флюида (скорость, температура, давление, плотность, концентрация примесей) испытывали хаотические флуктуации и потому изменялись от точки к точке и во времени нерегулярно. Хаотические флуктуации характеристик флюидного потока могли привести к распаду растворимых соединений золота, в качестве которых в золотоносных восстановленных флюидах выступают кластерные и элементоорганические соединения [4], и к осаждению его на локальных беспорядочно расположенных участках в виде тонкодисперсной примеси. Пробность золота в метасоматитах варьирует от 613 до $873 \%$, при этом в пирите она составляет 664-850\%, в анкерите $613-776 \%$, в сидерите 666-736\%, в сериците 708 и $768 \%$.

Линзо-пластообразные тела золотоносных метасоматитов, которые развиваются на контакте метагаббро, метагаббро-порфиритов и мраморизованных известняков, обладают зональным строением (табл. 1).

Формирование алюмосиликатных зон 01, 02, 03 метасоматической колонки сопровождается привносом углерода, калия, натрия, кальция, двухвалентного железа и выносом кремния, алюминия, трехвалентного железа, магния и титана. С увеличением интенсивности метасоматоза в направлении от зоны 01 к зоне 03 уменьшается кремнекислотность и увеличивется щелочность пород. Сравнительный анализ золотоносных метасоматитов, слагающих зоны 01, 02 и 03, показал отсутствие между метасоматитами значимых различий по содержанию золота [9].

К жильным гидротермалитам относятся кварцевые, кварц-альбитовые, кварц-кальцитовые и кварц-альбит-анкеритовые жилки мощностью 0,1-2,0 мм, секущие метасоматиты. В составе жилок кварц представлен как минимум двумя генерациями. Кварц ранней генерации слагает кварцанкеритовые прожилки, которые рассекаются прожилками кварца второй генерации с гребенчатой структурой и крустификационной текстурой. Иногда в составе жилок содержится примесь сульфидов, в основном пирита.

Реже наблюдаются секущие жилы кварца мощностью от первых до нескольких десятков сантимет-

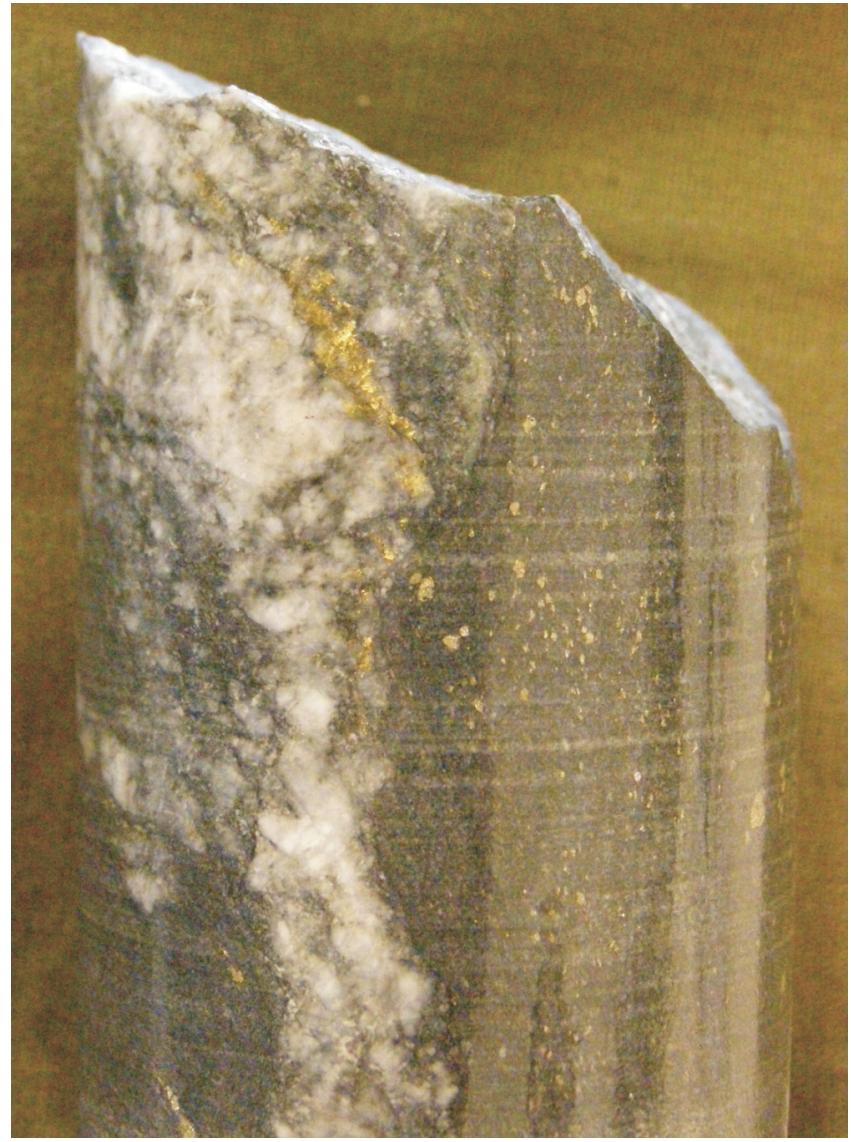

Рис. 3. Жила кварца (белое) с видимым золотом (желтое). Кедровское золоторудное проявление (скв. 53, гл. 90,5 м)

ров. Некоторые из них золотоносные. В зальбандах одного из кварцевых прожилков мощностью до 1,01,5 см отмечено видимое золото (рис. 3). Встречены жилы кварца с содержанием золота 9,9 и 17,15 г/т (данные пробирного анализа).

Таким образом, на Кедровском проявлении встречены два типа пород, несущих золотое оруденение, - это березитоподобные метасоматиты, слагающие крупные линзо-пластообразные рудные тела, прогнозные ресурсы которых по категории $\mathrm{P}_{1}$ составляют 77 т [2], и секущие их кварцевые жилы, на долю которых приходится менее 1 \% объема рудных тел. Всего в верховьях рч. Федоровка, Веселая и Магызы выявлены 74 кварцевые жилы. В 22 из них отмечалось видимое золото, но только четыре жилы отработаны, из них добыто 247,1 кг золота [14].

Геотермобарометрические исследования метасоматитов выполнены с применением кальцит-

Таблица 1

Метасоматическая колонка [20] линзо-бластовых тел золотоносных метасоматитов

\begin{tabular}{|c|c|c|c|c|c|}
\hline 00 & 01 & 02 & 03 & 1 & 0 \\
\hline Метагаббро & $\begin{array}{c} \pm \text { Сер }+ \text { Хл + Ка + } \\
\text { Аб }+ \text { Кв }+ \text { Грф }\end{array}$ & $\begin{array}{c}\text { Хл + Сер + Анк + } \\
\text { Аб + Кв + Грф }\end{array}$ & $\begin{array}{c}\text { Cep } \pm \text { Аб }+ \text { Aнк }+ \\
Г р \phi\end{array}$ & $\begin{array}{l}\text { Cep +Aб + Fe- } \\
\text { кальцит + Грф }\end{array}$ & Известняки \\
\hline
\end{tabular}

Примечание. Условные обозначения минералов: Аб - альбит, Анк - анкерит, Грф-графит, Кв - кварц, Сер - серицит, Хл - хлорит. Двойной вертикальной чертой разделены апокарбонатные и апоалюмосиликатные зоны метасоматической колонки. 


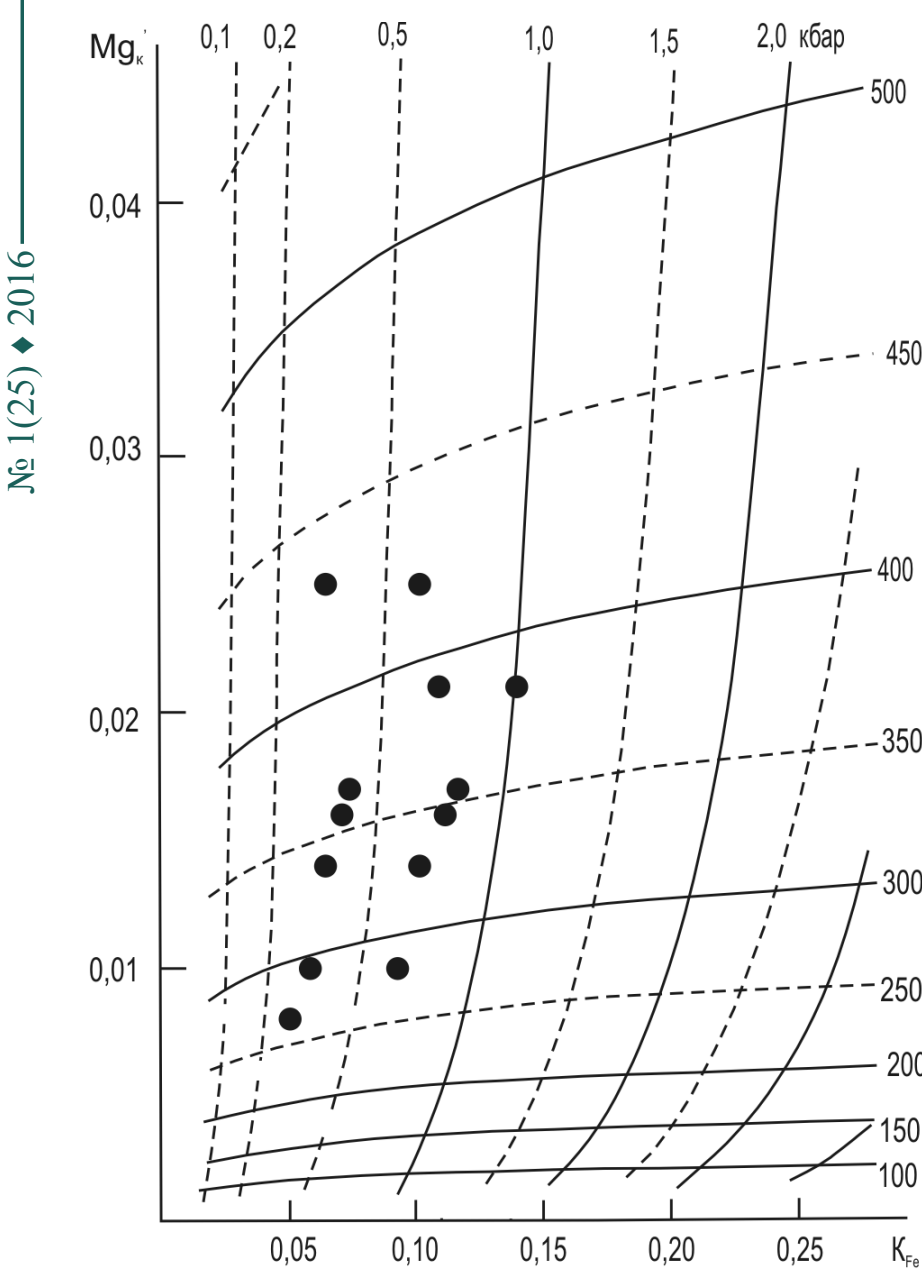

Рис. 4. Диаграмма кальцит-доломитового геотермобарометра и положение на ней фигуративных точек парагенезисов кальцит - анкерит (•) из метасоматитов Кедровского проявления

$\mathrm{Mg}_{\mathrm{k}}=\mathrm{Mg}_{\mathrm{k}}\left(1+11,5 \mathrm{Fe}_{\mathrm{k}}+5 \mathrm{Fe}_{\mathrm{k}}{ }^{2+}+550 \mathrm{Fe}_{\mathrm{k}}{ }^{3+}+8 \mathrm{Mn}_{\mathrm{k}}-50 \mathrm{Mn}_{\mathrm{k}}{ }^{2+}\right)$, где $\mathrm{Mg}_{\mathrm{k}}, \mathrm{Fe}_{\mathrm{k}}, \mathrm{Mn}_{\mathrm{k}}-$ молекулярные количества магния, железа и марганца в кальците; $\mathrm{K}_{\mathrm{Fe}}=\mathrm{Fe}_{\mathrm{k}} /\left(\mathrm{Fe}_{\mathrm{A}}+\mathrm{Mn}_{\mathrm{A}}\right)$, где $\mathrm{Fe}_{\mathrm{k}}, \mathrm{Fe}_{\mathrm{A}}$ и $\mathrm{Mn}_{\mathrm{A}}$ - молекулярные количества железа в кальците, железа и марганца в анкерите [22]

доломитового геотермобарометра А. С. Таланцева [22] и пирит-пирротинового геотермометра Р. Арнольда [15]. Значения оценочных РТ-параметров отражены на рис. 4, 5.

По кальцит-доломитовому геотермобарометру золотоносные метасоматиты формировались при температуре примерно $250-420^{\circ} \mathrm{C}$ и давлении 0,21,0 кбар (см. рис. 4), а по пирит-пирротиновому геотермометру примерно от 290 до $420{ }^{\circ} \mathrm{C}$ (см. рис. 5).

По опубликованным данным, температура процесса березитизации колеблется в пределах 450-250 ${ }^{\circ} \mathrm{C}$ при давлении 0,5-2,0 кбар [17], тогда как по результатам экспериментальных исследований (рис. 6), даже при высокой мольной доле $\left(\mathrm{X}_{\mathrm{CO}_{2}}\right)$ температура березитизации не превышает $380{ }^{\circ} \mathrm{C}$ (см. рис. 6, б). Выше этой температуры развиваются кварц-серицитовые метасоматиты (см. рис. 6, а). Нижняя температурная граница березитизации определяется сменой серицита смешанослойными слюдами смектитового типа и другими глинистыми

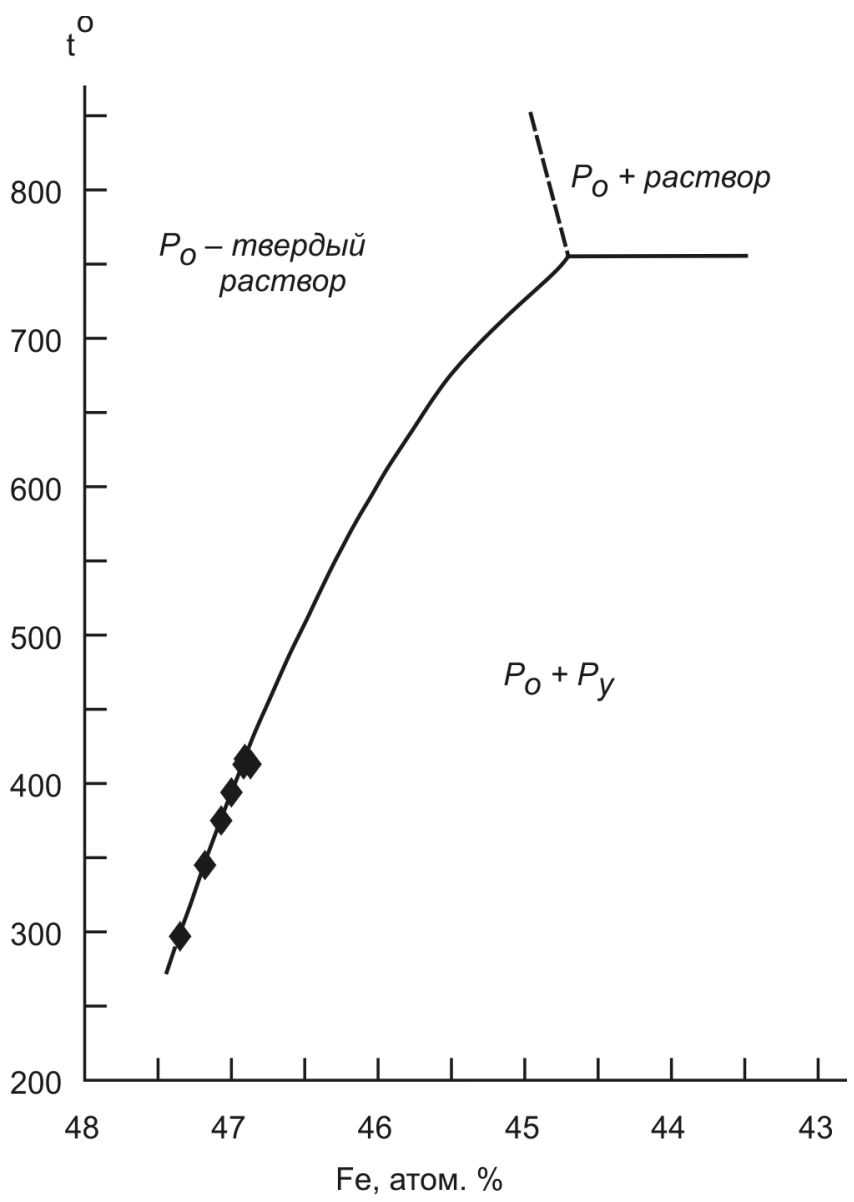

Рис. 5. Кривая зависимости состава пирротина от температуры образования по Р. Арнольду [15] и положение на ней пирротинов из парагенных пар пирит - пирротин (•) золотоносных метасоматитов Кедровского проявления

минералами, которые неустойчивы при температуpe $250{ }^{\circ} \mathrm{C}$ и выше [18].

Таким образом, данные о РТ-условиях образования березитоподобных золотоносных метасоматитов Кедровского участка в общем согласуются с опубликованными ранее результатами геотермобарометрических и экспериментальных исследований процесса березитизации.

Формационная принадлежность метасоматитов и гидротермалитов. По составу минеральных парагенезисов и температурам образования золотоносные метасоматиты Кедровского проявления могут быть отнесены к кварц-анкеритсерицитовой фации березитов и березитизированных пород [18] и названы березитоподобными метасоматитами. Золотооруденение в них представлено золотосульфидным минеральным типом, а в секущих метасоматиты кварцевых жилах и штокверках - золотокварцевым или золото-сульфидно-кварцевым типом.

Углеродистое вещество в виде графита на Кедровском участке является типоморфной примесью золотоносных метасоматитов, гидротермалитов и вмещающих пород. Графитизация локализуется вдоль рудоконтролирующих тектонических зон рассланцевания, катаклаза, брекчирования, будинажа 
$\mathrm{T},{ }^{\circ} \mathrm{C}$

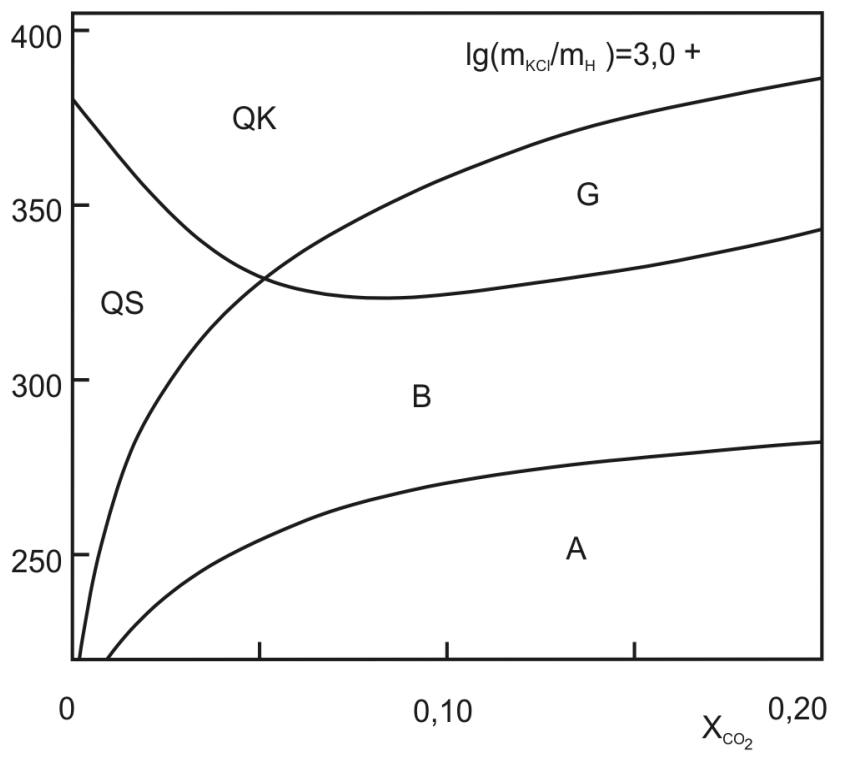

6

$\mathrm{T},{ }^{\circ} \mathrm{C}$

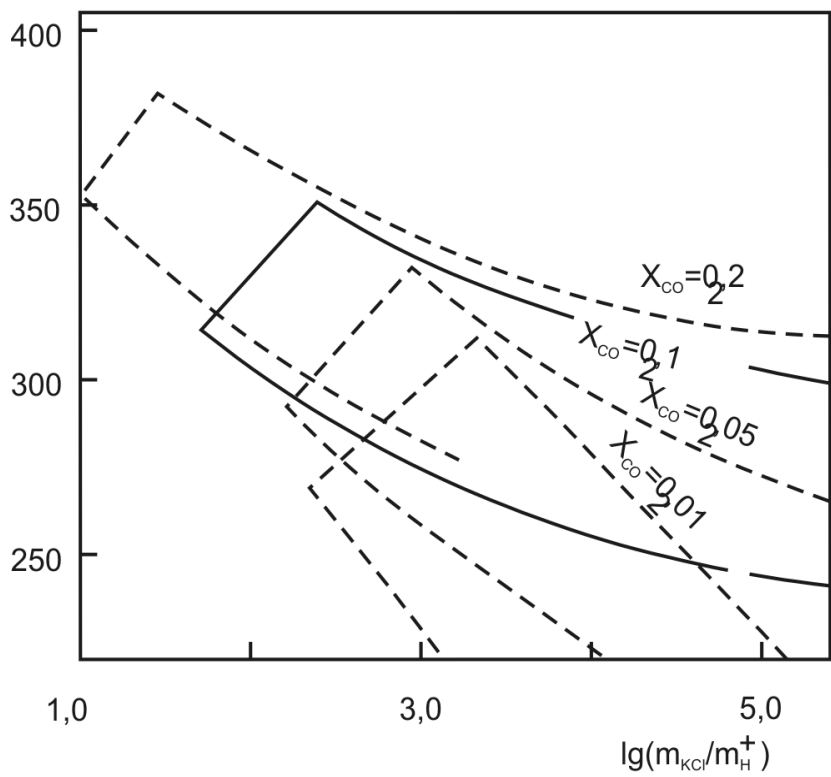

Рис. 6. Физико-химические условия образования березитов и других средне-низкотемпературных кислотных метасоматитов по данным экспериментального моделирования [18]

Диаграммы: а $-T-X_{\mathrm{cO}_{2}}$ при $\lg \left(m_{\mathrm{kCl}} / m_{\mathrm{H}^{-}}\right)=3,0 ; P_{\mathrm{H}_{2} \mathrm{O}+\mathrm{CO}_{2}}$ везде равно 1 кбар; б - для поля березитов при различных значениях мольной доли $\mathrm{CO}_{2}$ в $\mathrm{H}_{2} \mathrm{O}-\mathrm{CO}_{2}$ флюиде $X_{\mathrm{cO}_{2}}=0,01 ; 0,05 ; 0,1 ; 0,2$; поля: А - аргиллизитов, В - березитов, $\mathrm{G}$ - гумбеитов, QS - кварц-серицитовых метасоматитов, QK - кварц-калишпатовых метасоматитов

и интенсивной гидротермально-метасоматической проработки пород.

Графит образует мельчайшие (менее 0,001 мм в поперечнике) включения, ветвистые микрожилки толщиной 0,005-0,010 мм, пленки, примазки в зернах породообразующих минералов метасоматитов, кварце в гидротермалитах, в метагаббро, и мраморизованных известняках. Иногда в метасоматитах графит слагает тончайшие (толщиной 0,005-0,010 мм) оторочки вдоль зальбандов разноориентированных серицитовых жилок толщиной 0,10-0,15 мм, к которым приурочены мелкая вкрапленность и небольшие линзовидные скопления сульфидов.

В отраженном свете чешуйки графита обнаруживают двуотражение и анизотропию, окраска их меняется от коричневато-серой до светло-серой. Микрочешуйчатые агрегаты графита содержат мелкие (до 0,01 мм по удлинению) призматические зерна рутила (?).

На рис. 7 приведены результаты дериватометрического анализа графита из нерастворимого остатка мраморизованных известняков и из жилки углеродистого вещества в золотоносных метасоматитах. Для сравнения использованы термограммы графитов из метаморфических пород разной степени метаморфизма (см. рис. 7, III, IV).

Как показал сравнительный анализ дифференциальных кривых нагревания (ДТА) графита из мраморизованных известняков Кедровского проявления, он характеризуется отчетливо выраженным экзотермическим пиком, начало и конец которого приходятся на температурный интервал 570-580 и 750-770 ${ }^{\circ} \mathrm{C}$ соответственно, а максимум располагается в интервале температур 680-710 ${ }^{\circ} \mathrm{C}$ (см. рис. 7, І). Подобный режим выгорания свой-

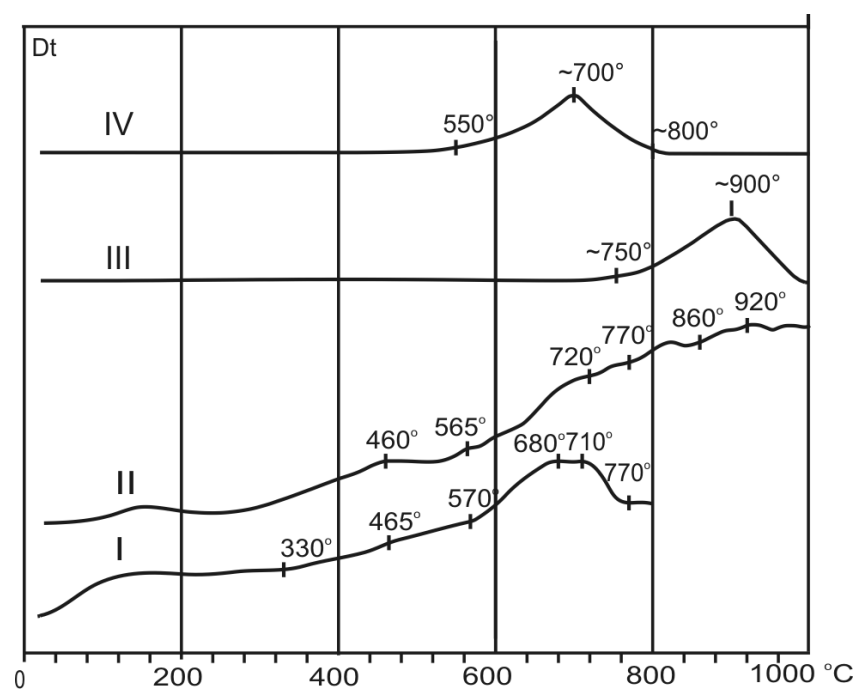

Рис. 7. Результаты дериватометрического анализа углеродистого вещества мраморизованных известняков (I) и золотоносных метасоматитов (II) Кедровского проявления I - графитсодержащий мраморизованный известняк, калтасский зеленосланцевый комплекс раннего рифея, траншея 11, инт. 20,0 м, обр. Т-11-20; II - жилка графита в серицит-анкеритовом метасоматите, скв. 2, гл. 54,5 м, обр. C-2-12; III, IV - метаморфогенные графиты (указаны температуры начала и окончания экзотермического эффекта) [3]: III - амфиболитовая фация, IV - фация зеленых сланцев (мусковит-хлоритовая субфация) 
ственен графитам из пород мусковит-хлоритовой субфации зеленосланцевой фации прогрессивного метаморфизма (см. рис. 7, IV).

Наиболее высокой температурой выгорания $\left(920{ }^{\circ} \mathrm{C}\right)$, сопоставимой с таковой графита из пород амфиболитовой фации (см. рис. 7, III), характеризуется графит, слагающий субпараллельные жилки толщиной 2-3 мм в золотоносных метасоматитах Кедровского проявления (см. рис. 7, II).

Цель изотопных исследований углерода графита и карбонатов - выявление природы источников углерода, входящего в состав графита золотоносных метасоматитов и гидротермалитов, а также вмещающих пород Кедровского золоторудного проявления (табл. 2).

В соответствии с существующими представлениями графит в породах мог кристаллизоваться: 1) при метаморфизме органического вещества, 2) при контактовом взаимодействии магмы с карбонатными породами, 3) при воздействии на породы углеродсодержащих магматогенных гидротермальных растворов. В качестве источника углерода при петро- и рудогенезе следует также назвать и глубинные (интрателлурические) флюиды - продукты дегазации мантии Земли. Проникая в земную кору вдоль зон глубинных разломов, они привносят углерод в форме $\mathrm{CO}_{2}, \mathrm{CO}, \mathrm{H}_{2} \mathrm{CO}_{3}, \mathrm{HCO}_{3}{ }^{1-}, \mathrm{CO}_{3}{ }^{2-}, \mathrm{CH}_{4}$ и др. Привнос мантийного углерода в земную кору подтверждается результатами изотопных исследований вулканических газов Камчатки, в которых существует корреляционная связь между изотопным составом гелия и углерода: чем выше доля мантийного гелия в газах, тем более изотопно тяжелым становится метан. При этом углерод метана мантийного происхождения характеризуется $\delta^{13} \mathrm{C} \approx-15 \%$ [7].

По изотопному составу углерода графиты Кедровского проявления можно разбить на две группы: изотопно "тяжелые» и изотопно «легкие ${ }^{1}$ графиты. В группу изотопно «тяжелых» входят мелкочешуйчатые графиты мраморизованных известняков, $\delta^{13} \mathrm{C}=-8,4 \ldots-11,0$ \%о (см. табл. 2, пробы 1-4). Поскольку изотопно "тяжелые» графиты в известняках находятся в ассоциации с кальцитом, утяжеление изотопного состава углерода могло произойти в процессе регионального метаморфизма путем изотопного обмена между графитом и ассоциирующим с ним карбонатом. Так как региональный метаморфизм осуществлялся в условиях, близких к условиям физико-химического равновесия, процессы изотопного обмена также должны были протекать в равновесных условиях и, следовательно, контролироваться термодинамическим изотопным эффектом. В этом случае определенной температуре изотопного обмена должно соответствовать определенное значение $\Delta_{\text {кг }}=\delta^{13} C_{k}-\delta^{13} C_{\text {г }}$ где кг - карбонатграфит, к-карбонат, г- графит. На рис. 8 видно, что

${ }^{1}$ При классификации изотопного состава углерода используется терминология Э. М. Галимова [6]. фигуративные точки, отвечающие изученным парам кальцит - графит, резко отклоняются от расчетных кривых и не соответствуют равновесным условиям изотопного обмена. Это позволяет предположить, что минеральная ассоциация кальцит- графит в мраморизованных известняках Кедровского проявления не равновесна. Графит в ней обнаруживает признаки более поздней кристаллизации, что подтверждается наличием секущих жилок графита в кальците.

Наложенный характер и особенности изотопного состава углерода изотопно "тяжелых» графитов в мраморизованных известняках Кедровского проявления позволяет высказать предположение, что образование их могло быть связано с воздействием глубинных флюидов. Согласно гипотезе Э. М. Галимова [6], углерод в мантии представляет собой не гомогенное вещество, обладающее единым изотопным составом, а, как в метеоритах, находится в двух различных фазах: 1) «концентрированной» изотопно «тяжелой» ( $\delta^{13} \mathrm{C}=-7,0 \%$ в в виде графита и углистого вещества, 2) "рассеянной» изотопно "легкой» $\left(\delta^{13} \mathrm{C}=-22,7 \%\right.$ в) в виде соединений с металлами. Будучи химически более реакционноспособным, изотопно «тяжелый» углерод мог экстрагироваться из мантийного субстрата интрателлурическими флюидами и в форме $\mathrm{CO}_{2}, \mathrm{CO}, \mathrm{CH}_{4}, \mathrm{CO}_{3}{ }^{2-}$ и др. привноситься в земную кору, в частности по КузнецкоАлтайскому глубинному разлому, приводя к графитизации рудовмещающей толщи Кедровского проявления на регрессивном этапе регионального метаморфизма. Отсутствие изотопно "тяжелых» графитов в составе золотоносных метасоматитов и гидротермалитов при наличии их в рудовмещающих породах свидетельствует о том, что графитизация с выделением изотопно "тяжелых» графитов происходила в дорудную стадию процесса рудогенеза.

Группа изотопно "легких" графитов объединяет графиты с $\delta^{13} \mathrm{C}=-19,6 . . .-24,9$ \%о (см. табл. 2, пробы 5-9). Они слагают секущие жилки в брекчированных золотоносных метасоматитах (пробы 6-8), в секущей метасоматиты кварцевой жилке (проба 5), брекчированном и окварцованном метааргиллите (проба 9). В эту группу включен также графит из раннепротерозойских кварц-роговообманковых кристаллических сланцев, слагающих нижний структурный этаж Томского выступа и подстилающих зеленосланцевую толщу калтасского рудовмещающего комплекса (проба 10).

На природу углерода изотопно «легких» графитов Кедровского проявления были высказаны две альтернативные точки зрения [10]. Согласно одной из них, источником углерода служило органическое вещество, другой - мантия.

Вторая гипотеза подтверждается:

- пространственной приуроченностью метасоматитов и гидротермалитов с изотопно «легким» графитом к Кузнецко-Алтайскому глубинному разлому - проводнику интрателлурических флюидов; 
Изотопный состав углерода графитов из вмещающих пород, золотоносных метасоматитов и гидротермалитов Кедровского золоторудного проявления ФМКЗ

\begin{tabular}{|c|c|c|c|}
\hline \multirow{2}{*}{$\begin{array}{c}\text { № } \\
\text { пробы }\end{array}$} & \multirow{2}{*}{ Характеристика графита Кедровского проявления } & \multicolumn{2}{|c|}{$\delta^{13} \mathrm{C}, \%$ o } \\
\hline & & Графит & Кальцит \\
\hline 1 & из графитсодержащего мраморизованного известняка & $-11,0$ & 6,5 \\
\hline 2 & « & $-8,4$ & 6,3 \\
\hline 3 & « & $-9,6$ & 6,9 \\
\hline 4 & $\begin{array}{c}\text { из графитовой жилки в графитсодержащем мраморизованном } \\
\text { известняке }\end{array}$ & $-10,5$ & - \\
\hline 5 & из кварцевой жилы, секущей метасоматиты & $-24,8$ & - \\
\hline 6 & из альбит-анкерит-серицитового метасоматита & $-24,9$ & - \\
\hline 7 & « & $-21,1$ & - \\
\hline 8 & « - - - - & $-19,8$ & - \\
\hline 9 & из брекчированного и окварцованного метааргиллита & $-19,6$ & - \\
\hline 10 & $\begin{array}{c}\text { из графитсодержащего кварц-актинолитового сланца терсинской свиты } \\
\text { раннего протерозоя (р. Томь у пос. Лужба) }\end{array}$ & $-21,1$ & - \\
\hline
\end{tabular}

Примечание. Кедровское проявление: 1 - графитсодержащий мраморизованный известняк, скв. 1, гл. 33,0 м, обр. С-13; 2 - то же, гл. 37,2 м, обр. С-1-4; 3 - то же, траншея 11, инт. 20,0 м, обр. Т-11-20; 4 - графитовая жилка в графитсодержащем мраморизованном известняке, скв. 1, гл. 146,0 м, обр. С-1-27; 5 - графитовая жилка в кварцевой жиле, секущей метасоматиты, скв. 2, гл. 60,5 м, обр. С-2-11; 6 - жилка графита в альбит-анкерит-серицитовом метасоматите, скв. 2, гл. 64,5 м, обр. С-2-12; 7 - то же, скв. 1, гл. 81,5 м, обр. С-1-11; 8 - то же, скв. 2, гл. 82,5 м, обр. С-2-17; 9 - графитсодержащий брекчированный и окварцованный метааргиллит, траншея 8, инт. 22,0 м, обр. Т-8-4; 10 - правый борт р. Томь в 2 км выше по течению от пос. Лужба, обр. 210-9.

- сходством изотопно «легких» графитов $\left(\delta^{13} \mathrm{C}=-19,6 . . .-24,9 \%\right.$ \% пи $\delta^{13} \mathrm{C}_{\mathrm{cp}}=-22,04 \%$ \%) с углеродом «рассеянной» фазы метеоритов $\left(\delta^{13} \mathrm{C}=-23,0 \%\right.$ ), а также магматических пород мантийного происхождения, например гипербазитов $\left(\delta^{13} \mathrm{C}=-22,7 \%\right.$ \%) [23].

- наличием значимого отличия углерода изотопно «легких» графитов Кедровского проявления от углерода из черных углеродисто-кремнистых сланцев, в которых $\delta^{13} \mathrm{C}=-27,7 . . .-33,8 \%$ [8];

- присутствием изотопно «легких» графитов в кристаллических сланцах терсинской свиты раннего протерозоя ( $\delta^{13} \mathrm{C}=-21,1 \%$ ) (см. табл. 2, проба 10), подстилающей метаморфические сланцы рудовмещающего калтасского комплекса раннего рифея.

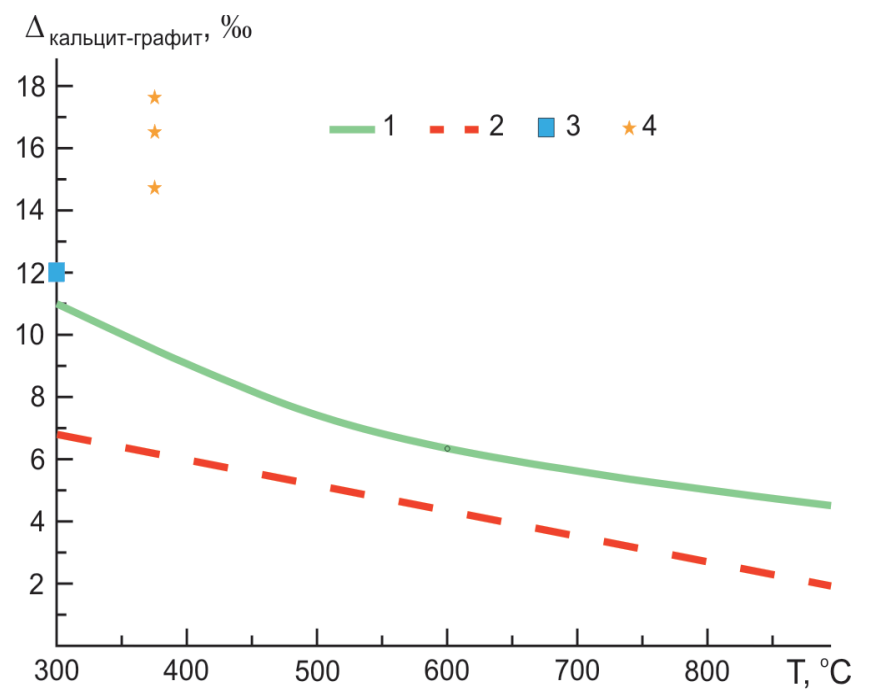

Рассмотренные особенности изотопного состава и геологической позиции изотопно «легких» графитов Кедровского проявления позволяют высказать предположение, что источником углерода для них был углерод, находящийся в мантии в «рассеянной» фазе и характеризующийся $\delta^{13} \mathrm{C}_{\mathrm{cp}}=-22,7 \%$ [23], что наблюдается в изверженных породах мантийного происхождения. На регрессивном этапе метаморфизма он извлекался интрателлурическими флюидами из мантийного субстрата и привносился в земную кору, локализуясь вдоль проницаемых зон рассланцевания, брекчирования и будинажа, которые в пределах Кедровского участка играли роль рудоконтролирующих структур.

Редкоземельные элементы (РЗЭ) относятся к числу наименее подвижных элементов. На них слабо влияют процессы гидротермального изменения и метаморфизма, вследствие чего их содержания и характер распределения наиболее точно отражают состав магматического или осадочного протолита метамор-

Рис. 8. Изотопные геотермометры для пары кальцит графит

1, 2 - температурные кривые: 1 - по данным У. Баттинга [28]; 2 - по данным Д. Вилли, О’Нила [29]; 3 - пара кальцит - графит из мраморизованных известняков большеказырской свиты среднего рифея, перекрывающей рудовмещающий калтасский зеленосланцевый комплекс и метаморфизованной в условиях пренит-пумпеллиитовой фации ( $\approx 300^{\circ} \mathrm{C}$ ) (см. табл. 4, проба 8); 4 - пары кальцит - графит из мраморизованных известняков калтасского зеленосланцевого комплекса, испытавших метаморфизм эпидот-актинолитовой субфации зеленосланцевой фации ( $\approx 380-420$ C) (см. табл. 4, пробы 1-3) 


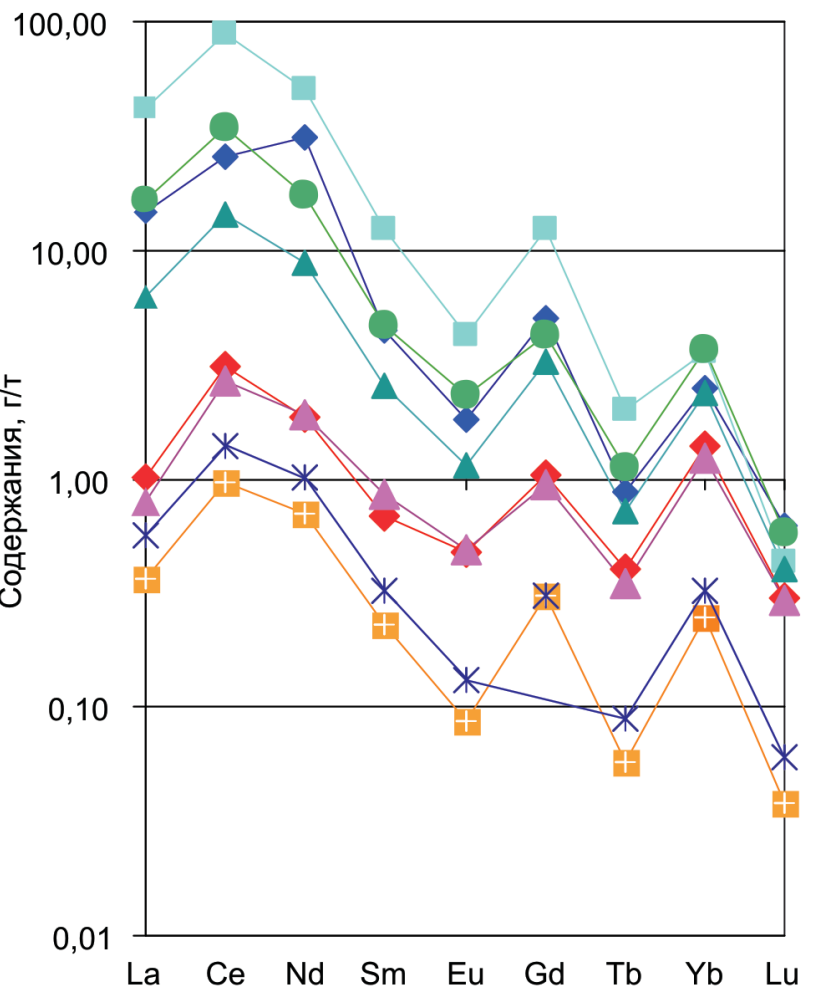

б

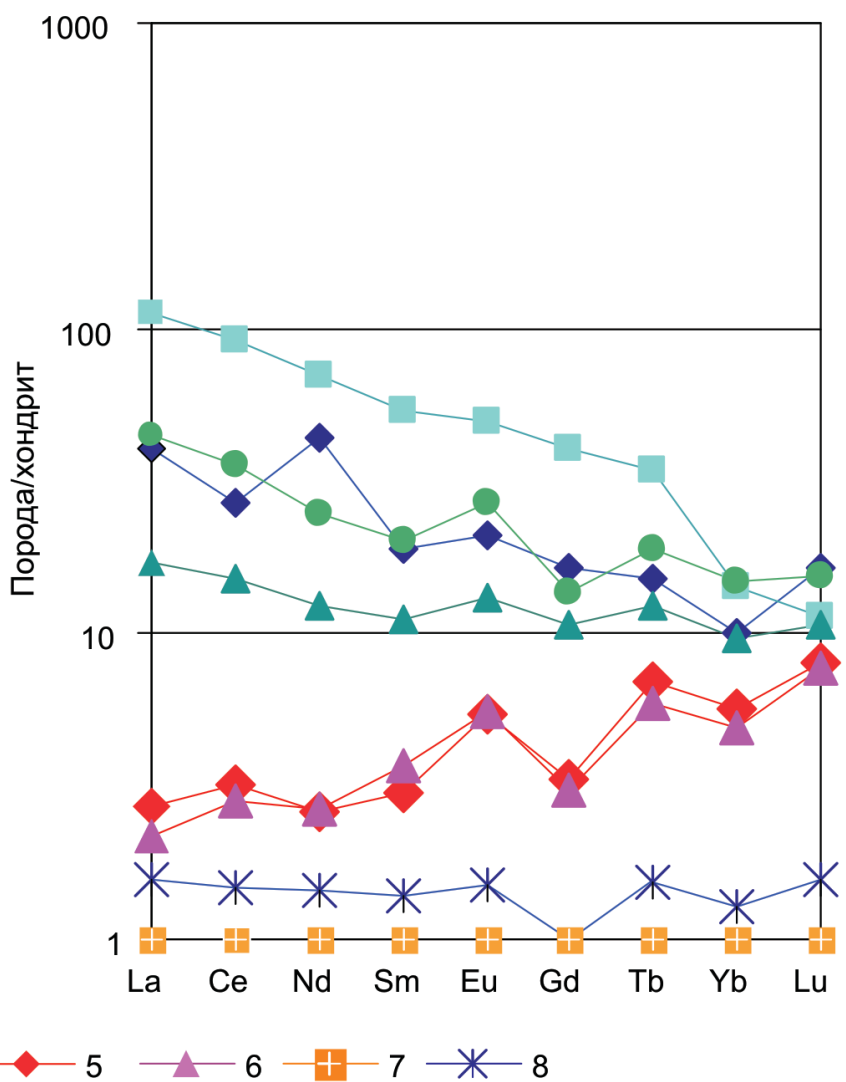

Рис. 9. Средние значения содержаний РзЭ (а) и они же нормированные (б) в золотоносных метасоматитах и вмещающих метаморфических сланцах ФМКЗ (Кузнецкий Алатау)

1 - аповулканитовые сланцы калтасского зеленосланцевого комплекса раннего рифея, руч. Бол. Удила; 2, 3 - аповулканитовые сланцы нижней (2) и верхней (3) толщ калтасского зеленосланцевого комплекса, Калтасское золоторудное проявление, руч. Калтас; 4 - метагаббро, Кедровское золоторудное проявление; 5, 6 - золоторудные (5) и золотосодержащие (6) апогаббровые метасоматиты, Кедровское проявление; 7 -хондриты [11]; 8 - первичная (неистощенная) мантия по Андерсену [11]

фических пород, а также его палеогеодинамические обстановки.

В соответствии с существующей классификацией [11] среди Р3Э выделяются следующие группы: 1) легкие (ЛР3Э) - La, Ce, Pr, Nd, Pm, Sm, Eu; 2) тяжелые (TP3Э) - Gd, Tb, Dy, Ho, Er, Tm, Yb, Lu. Вce P3Э имеют близкие химические и физические характеристики. Обычно они образуют ионы с зарядом +3, но в определенных условиях валентность отдельных элементов может быть другой: Се и Еu образуют ионы $\mathrm{Ce}^{4+}$ и $\mathrm{Eu}^{2+}$. Геохимическая специфика европия проявляется в так называемой европиевой аномалии (Euаномалии) (из примечания к табл. 3).

С целью изучения особенностей распределения Р3Э между графитсодержащими золотоносными метасоматитами Кедровского проявления, несущими золотое оруденение, и вмещающими породами был выполнен нейтронно-активационный анализ. Результаты были сгруппированы в несколько выборок, включающих золоторудные метасоматиты с содержанием золота 0,63-24,3 г/т, золотоносные метасоматиты (Au 0,006-0,079 г/т) и вмещающие метагаббро. Кроме того, для сравнения были использованы данные нейтронно-активационного анализа пород вмещающего калтасского зеленосланцевого комплекса раннего рифея [21]. Средние значения содержаний Р3Э по выборкам отражены в табл. 3 и на рис. 9, а. Для сглаживания трендов распределения РЗЭ применена процедура нормализации к стандарту, в качестве которого использовался хондритовый метеорит (см. рис. 9, б).

При анализе диаграммы на рис. 9, а обращает на себя внимание пилообразный характер трендов Р3Э. Это связано с тем, что РЗЭ с четными атомными номерами (Ce, Nd, Sm, Gd, Yb) более стабильны, чем с нечетными (La, Eu, Lu). Поэтому в природных объектах они встречаются в более высоких концентрациях. Для сглаживания трендов РЗЭ пользуются процедурой нормирования элементов по стандарту, в качестве которого часто используется хондритовый метеорит или примитивная мантия [11]. Диаграмма распределения нормированных по хондриту содержаний РЗЭ в породах Кедровского проявления (см. рис. 9, б) наглядно иллюстрирует ряд следующих закономерностей:

- по характеру наклона трендов распределения РЗЭ на Кедровском проявлении выделяются две группы пород: 1) золоторудные и золотосодер- 
Средние содержания Р3Э (г/т) в золотоносных метасоматитах и вмещающих породах Кедровского проявления ФМКЗ

\begin{tabular}{c|c|c|c|c|c|c|c|c|c|c|c|c}
\hline $\begin{array}{c}\text { № } \\
\text { пробы }\end{array}$ & $\mathrm{La}$ & $\mathrm{Ce}$ & $\mathrm{Nd}$ & $\mathrm{Sm}$ & $\mathrm{Eu}$ & $\mathrm{Gd}$ & $\mathrm{Tb}$ & $\mathrm{Yb}$ & $\mathrm{Lu}$ & $\Sigma$ & $\mathrm{Eu}^{\mathrm{Eu} *}$ & $\mathrm{La}_{\mathrm{N}} / \mathrm{Lu} \mathrm{N}_{\mathrm{N}}$ \\
\hline 1 & 14,75 & 25,50 & 30,91 & 4,41 & 1,83 & 5,00 & 0,88 & 2,51 & 0,63 & 86,41 & 1,19 & 2,42 \\
2 & 41,39 & 88,19 & 50,20 & 12,36 & 4,30 & 12,31 & 1,98 & 3,55 & 0,43 & 214,70 & 1,06 & 9,88 \\
3 & 6,23 & 14,36 & 8,80 & 2,55 & 1,15 & 3,26 & 0,71 & 2,39 & 0,41 & 39,88 & 1,22 & 1,59 \\
4 & 16,40 & 33,96 & 17,51 & 4,70 & 2,33 & 4,20 & 1,11 & 3,66 & 0,59 & 84,45 & 1,60 & 2,90 \\
5 & 1,00 & 3,06 & 1,87 & 0,69 & 0,47 & 1,03 & 0,40 & 1,41 & 0,30 & 10,23 & 1,71 & 0,34 \\
6 & 0,80 & 2,70 & 1,90 & 0,86 & 0,48 & 0,94 & 0,35 & 1,22 & 0,30 & 9,55 & 1,65 & 0,28 \\
7 & 0,37 & 0,96 & 0,71 & 0,23 & 0,09 & 0,31 & 0,06 & 0,25 & 0,04 & 3,00 & 1,00 & 1,00 \\
8 & 0,57 & 1,40 & 1,02 & 0,32 & 0,13 & 0,31 & 0,09 & 0,32 & 0,06 & 4,22 & 1,27 & 0,98
\end{tabular}

Примечание. 1 - аповулканитовые сланцы калтасского зеленосланцевого комплекса раннего рифея, руч. Бол. Удила; 2, 3 - аповулканитовые сланцы нижней (2) и верхней (3) толщ калтасского зеленосланцевого комплекса, Калтасское золоторудное проявление, руч. Калтас, 4 - метагаббро, Кедровское проявление; 5, 6 - золоторудные (5) и золотосодержащие (6) апогаббровые метасоматиты, Кедровскоепроявление, 7 - хондриты [11], 8 - первичная (примитивная) мантия по Андерсену [11]. Eu-аномалия ( $\mathrm{Eu} / \mathrm{Eu}^{*}=\mathrm{Eu}_{N} /\left[\sqrt{\mathrm{Sm}_{N} \mathrm{Gd}_{N}}\right]$ ) - это мера обеднения или обогащения европи-

ем относительно самария и гадолиния. Значения отношения Eu/Eu* менее 0,95 указывают на истощение, а значения более 1,05 - на обогащение европием относительно соседних Р3Э [11].

жащие березитоподобные метасоматиты, тренды которых имеют положительный наклон, 2) вмещающие метаморфические породы, тренды распределения РЗЭ которых имеют отрицательный наклон;

- в каждой группе тренды распределения РЗЭ характеризуются субпараллельной ориентировкой, что указывает на наличие геохимического родства, тогда как между породами разных групп оно отсутствует;

- породы выделенных групп различаются по суммарному содержанию РЗЭ: в группе золотоносных метасоматитов - 9,55-10,23 г/т, во вмещающих метагаббро и аповулканитовых сланцах - 84,45 и 39,88-214,70 г/т соответственно (см. табл. 3);

- по содержанию и характеру распределения РзЭ золоторудные и золотосодержащие метасоматиты, между которыми особенно высока степень геохимического сходства, по составу наиболее близки к первичной (неистощенной) мантии;

- золотоносные метасоматиты наиболее близки к первичной мантии по соотношению легких и тяжелых Р3Э: в группе метасоматитов $\mathrm{La}_{\mathrm{N}} / \mathrm{Lu}_{\mathrm{N}}=0,28$ 0,34, в то время как в метагаббро она возрастает до 2,9, а в аповулканитовых сланцах - до 1,59-9,88 (см. табл. 3);

- золотоносные метасоматиты отличаются от вмещающих пород наиболее высокими значениями Еu-аномалии $(1,65-1,71)$ (см. табл. 3), что свидетельствует о восстановительных условиях их формирования.

Поскольку метасоматитами наследуются геохимические особенности флюидогенерирующего очага и овеществляются признаки, позволяющие судить о физико-химических свойствах флюидов, можно предположить, что близость золотоносных метасоматитов Кедровского проявления к первич- ной мантии по содержанию и характеру распределения РЗЭ, отношению $\mathrm{La}_{\mathrm{N}} / \mathrm{Lu}_{\mathrm{N}}$ и сумме содержаний РЗЭ может рассматриваться в качестве одного из подтверждений мантийной природы рудоносных флюидов. Еще один аргумент - высокая степень восстановленности флюидов. Об этом свидетельствуют высокие значения Еu-аномалии в метасоматитах, что связано с восстановлением европия и увеличением в его составе содержания иона $\mathrm{Eu}^{2+}$ согласно переходу $\mathrm{Eu}^{3+} \rightarrow \mathrm{Eu}^{2+}$.

Восстановительные условия формирования золотоносных метасоматитов на Кедровском проявлении, помимо высоких значений Еu-аномалии, подтверждаются присутствием в них примеси графита и составом рудных минералов. Они представлены сульфридами (пирит, пирротин, халькопирит, сфалерит, галенит), сульфоарсенидами (кобальтин, герсдорфит, арсенопирит), арсенидами, сульфосолями (теннантит, тетраэдрит, фрейбергит), а также самородными металлами - палладием [13] и висмутом [1].

Завершая рассмотрение Кедровского золоторудного проявления ФМКЗ, необходимо подчеркнуть следующие его особенности:

- размещение в краевой зоне крупной (радиусом 400 км) Кузнецко-Алатауско-Саянской кольцевой морфоструктуры центрального типа, возникшей в результате проявления в раннем рифее масштабной плюмтектоники и сопутствующего ей континентального рифтогенеза;

- пространственная связь с Кузнецко-Алтайским глубинным разломом, представляющим собой дуплекс растяжения Кузнецко-Алатауско-Саянской морфоструктуры;

- приуроченность к Томскому выступу древнего кристаллического фундамента, обнажающемуся вдоль глубинного разлома; 
- размещение среди раннерифейского зеленосланцевого комплекса, слагающего верхний (супраструктурный) этаж Томского выступа;

- наличие в составе вулканогенного протолита рудовмещающего зеленосланцевого комплекса продуктов мантийного магматизма;

- геохимическую специализацию на золото рудовмещающего зеленосланцевого комплекса;

- рудоконтролирующую роль тектонических зон рассланцевания, катаклаза, брекчирования, будинажа и интенсивной гидротермально-метасоматической проработки пород;

- приуроченность основного объема золотого оруденения к линзо-пластообразным телам сланцеватых метасоматитов и незначительной части к кварцевым жилам и штокверкам, секущим метасоматиты;

- принадлежность золотоносных метасоматитов серицит-кварц-альбит-анкеритового состава, образовавшихся при температурах 420-290 ${ }^{\circ} \mathrm{C}$ и давлениях 0,2-1,0 кбар, к кварц-анкерит-серицитовой фации формации березитов и березитизированных пород, а оруденения в них - к золотосульфидному минеральному типу, тогда как в кварцевых жилах и штокверках оруденение представлено золотокварцевым или золото-сульфидно-кварцевым типом;

- тонкодисперсный характер оруденения в метасоматитах, содержащих мельчайшие (от 0,001×0,003 до 0,009×0,016 мм) неравномерно распределенные включения золота, тогда как в кварцевых жилах и штокверках оруденение носит более крупнозернистый характер, вплоть до визуально фиксируемых выделений золота;

- наличие в золотоносных метасоматитах и гидротермалитах типоморфной примеси графита, характеризующегося мантийной изотопией углерода;

- стадийность процесса графитизации с кристаллизацией на предрудной и рудной стадиях рудогенеза графитов с изотопно "тяжелым» $\left(\delta^{13} \mathrm{C}=-8,4 \ldots\right.$ $-11,0 \%$ и и изотопно «легким» $\left(\delta^{13} \mathrm{C}=-19,6 \ldots\right.$ $-24,9 \%$ ) углеродом соответственно;

- близость золотоносных метасоматитов к первичной (неистощенной) мантии по содержанию и характеру распределения РЗЭ;

- аномально высокие положительные значениями Eu-аномалии в золотоносных метасоматитах, свидетельствующие о восстановительных условиях их формирования;

- сходство сланцеватых золотоносных метасоматитов Кедровского проявления с графитсодержащими синтектоническими метасоматитами зон глубинных разломов [19], которые формировались в земной коре в условиях интенсивного массопереноса восстановленными мантийными флюидами петрогенных и рудных компонентов.

Рассмотренные особенности вещественного состава и условий образования Кедровского золоторудного проявления нетрадиционного типа позволяют отнести его к классу мантийных место- рождений (по А. Д. Щеглову, И. Н. Говорову [26]), которые сформировались в земной коре в результате проявления флюидного мантийно-корового рудогенеза, протекавшего в земной коре при участии интрателлурических флюидов в условиях гетерогенности рудного вещества, но с доминирующей ролью мантийного. Выявленные особенности рудогенеза могут быть использованы в качестве поисковых критериев золоторудных месторождений в докембрийских зеленосланцевых комплексах складчатых областей.

\section{СПИСОК ЛИТЕРАТУРЫ}

1. Алабин, Л. В. Геологическое строение и перспективы Федоровско-Магызинской золоторудной зоны (Кузнецкий Алатау) [Текст] / Л. В. Алабин // Петрология магматических и метаморфических комплексов. Вып. 3. Т. ІІ. - Томск, 2002.

2. Белоножко, Е. А. Кедровское рудопроявление Федоровско-Кедровского рудного поля в Ортон-Балыксинском рудном районе (Республика Хакасия) [Текст] / Е. А. Белоножко // Геология, геофизика и минеральное сырье Сибири : матер. 2-й науч.-практ. конф. Т. 2. - Новосибирск : СНИИГГиМС, 2015 - С. $120-122$

3. Блюман, Б. А. Применение термического анализа для определения степени метаморфизма графитсодержащих мраморов нагорья Сангилен (Юго-Восточная Тува) [Текст] / Б. А. Блюман, В. П. Иванова, Т. Н. Красавина // Изв. АН СССР. 1969. - № 8. - С. 125-132.

4. Буслаева, Е. Ю. Элементоорганические соединения в проблеме миграции рудного вещества [Текст] / Е. Ю. Буслаева, М. И. Новгородова. - М. : Недра, 1989. - 151 с.

5. Ведерников, П. Г. Рудное поле. Теоретические и практические вопросы изучения [Текст] / П. Г. Ведерников. - Владивосток, 1989. - 111 с.

6. Галимов, э. М. Геохимия стабильных изотопов углерода [Текст] / Э. М. Галимов. - М. : Недра, 1968.- 222 с.

7. Гелий и метан верхней мантии Земли в газах Камчатки [Текст] / И. Л. Каменский, В. А. Лобков, Э. М. Прасолов [и др.] // V Всесоюз. симп. по геохимии стабильных изотопов : тез. докл. - М., 1974. С. 148-149.

8. Ермолаев, Н. П. Стратиформное рудообразование в черных сланцах [Текст] / Н. П. Ермолаев, Н. А. Созинов. - М. : Наука, 1986. - 173 с.

9. Золотоносные синтектонические метасоматиты - руды крупнообъемных месторождений золота нетрадиционного типа [Текст] / А. Б. Шепель, М. Е. Гавриленко, В.П.Лепилин, Е.А.Белоножко // Геология и минерагения Сибири. - Новосибирск : СНИИГГиМС, 2010. - С. 45-56.

10. Изотопные исследования углерода и кислорода золоторудных проявлений Федоровско-Магызы-Калтасской зоны (Кузнецкий Алатау, Горная Шория) [Текст] / А. Б. Шепель, С. И. Голышев, Н. Л. Па- 
далко [и др.] // XVIII симпозиум по геохимии изотопов им. акад. А. П. Виноградова : тез. докл. - М., 2007. - C. 289-290.

11. Интерпретация геохимических данных : учеб. пособие [Текст] / под ред. Е. В. Склярова. - М. : Интермет инжиниринг, 2001. - 287 с.

12. Караганов, В. В. Итоги работы государственной геологической службы за 2001 г. и приоритетные направления деятельности МПР России в развитии минерально-сырьевой базы России и ее континентального шельфа в 2002 г. [Текст] / В. В. Караганов // Минеральные ресурсы России. Экономика и управление. - 2002. - № 1-2. - С. 4-11.

13. Конышев, В. О. Месторождение Федоровское-1 и особенности методики разведки объектов с крупными выделениями самородного золота в рудах (Кузнецкий Алатау) [Текст] / В. О. Конышев, Е. В. Севастьянов, Г. Н. Власов // Геология и минеральные ресурсы Центральной Сибири. - Красноярск, 2003. - С. 146-156.

14. Конышев, В. О. Федоровско-Кедровское золоторудное поле - литолого-стратиграфический контроль золотоносности [Текст] / В. О. Конышев // Отечественная геология. - 2006. - № 2. - С. 13-20.

15. Краткий справочник по геохимии [Текст] / Г. В. Войткевич, А. Е. Мирошников, А. С. Поваренных, В. Г. Прохоров. - М. : Недра, 1970. - 277 с.

16. Летников, Ф. А. Автономные флюидные системы континентальной земной коры [Текст] / Ф. А. Летников // Докл. РАН. - 2009. - Т. 427, № 6. C. 810-813.

17. Мартынов, К. В. Карбонатные парагенезисы березитов-лиственитов на месторождениях малосульфидной формации Среднего Урала [Текст] / К. В. Мартынов // Геология рудных месторождений. - 1992. - Т. 31, № 5. - С. 46-56.

18. Метасоматизм и метасоматические породы [Текст] / под ред. В. А. Жарикова, В. Л. Русинова. - М. : Научный мир, 1998. - 492 с.

19. Метаморфизм и метасоматоз в зонах глубинных разломов континентальной литосферы [Текст] / Ф. А. Летников, В. Б. Савельев, Д. Е. Гореванов, В. А. Халилов // Геотектоника. - 1996. - № 5. C. $15-26$.

20. Перспективы поисков крупнообъемных золоторудных месторождений нетрадиционного типа в западной части Алтае-Саянской складчатой области [Текст] / А. Б. Шепель, М. Е. Гавриленко, В. П. Лепилин, Е. А. Белоножко // Геология и минерагения Сибири. - Новосибирск : СНИИГГиМС, 2010. - С. 33-45.

21. Схемы межрегиональной корреляции магматических и метаморфических комплексов АлтаеСаянской складчатой области и Енисейского кряжа [Текст] / отв. ред. В. Л. Хомичев. - Новосибирск : СНИИГГиМС, 2002. - 178 с.

22. Таланцев, А. С. Геотермобарометрия по доломит-кальцитовым парагенезисам [Текст] / А. С. Таланцев. - М. : Наука, 1981. - 136 с.
23. Тугаринов, А. И. Общая геохимия [Текст] / А. И. Тугаринов. - М. : Атомиздат, 1973. - 288 с.

24. Шепель, А. Б. Перспективы золотоносности и поисков крупнообъемных месторождений золота нетрадиционного типа в докембрийских зеленосланцевых комплексах западной части Алтае-Саянской складчатой области [Текст] / А. Б. Шепель, М. Е. Гавриленко // Золото Сибири и Дальнего Востока: геология, геохимия, технология, экономика, экология : тез. 3-го Всерос. симп. с междунар. участием. - Улан-Удэ : Изд-во БНЦ СО РАН, 2004. C. $245-247$.

25. Шепель, А. Б. Структурные аспекты корреляции метаморфических комплексов Алтае-Саянской складчатой области [Текст] / А. Б. Шепель, М. Е. Гавриленко, В. П. Лепилин // Материалы региональной конференции геологов Сибири, Дальнего Востока и Северо-Востока России. Т. І. - Томск, 2000. - С. 90-92.

26. Щеглов, А. Д. Нелинейная металлогения и глубины Земли [Текст] / А. Д. Щеглов, И. Н. Говоров. - М. : Наука, 1985. - 325 с.

27. Щербаков, Ю. Г. Геохимия золоторудных месторождений в Кузнецком Алатау и Горной Шории [Текст] / Ю. Г. Щербаков. - Новосибирск : Наука, 1974. -278 c.

28. Bottinga, Y. Calculated fractionation factor for carbon and hydrogen isotope exchange in the system calcite - carbon dioxide - graphite - aethane - hidrogen - water [Text] / Y. Bottinga // Geochim. et Cosmochim. Acta. - 1969. - Vol. 33, N 1. - P. 49.

29. Valley, J. ${ }^{12} \mathrm{C} /{ }^{13} \mathrm{C}$ exchange between calcite and graphite a possible thermometer in Grenvile marblee [Text] / J. Valley, J. R. O'Neil // Geochim. et Cosmochim. Acta. - 1981. - Vol. 15, N 5. - P. 411-419.

\section{REFERENCES}

1. Alabin L.V. [Geological structure and prospects of the Fedorovsko-Magyzynskaya gold-ore zone (Kuznetsk Alatau)]. Petrologiya magmaticheskikh i metamorficheskikh kompleksov - Petrology of magmatic and metamorphic zomplexes, Tomsk, 2002, issue 3, vol. 2. (In Russ.).

2. Belonozhko E.A. [The Kedrovskoye ore show of the Fedorovsko-Kedrovskoye ore field in the OrtonBalyksa ore region (Republic of Khakassia]. Geologiya, geofizika i mineral'noe syr'e Sibiri: Materialy vtoroy nauchno-prakticheskoy konferentsii [Geology, Geophysics and Mineral Resources of Siberia: Proc. the second research and practice conference]. Novosibirsk, SNIIGGiMS, 2015, vol. 2, pp. 120-122. (In Russ.).

3. Blyuman B.A., Ivanova V.P., Krasavina T.N. Primenenie termicheskogo analiza dlya opredeleniya stepeni metamorfizma grafitsoderzhashchikh mramorov nagor'ya Sangilen (Yugo-Vostochnaya Tuva) [Applying the thermal analysis to determine the degree of metamorphism of graphite-bearing marble in the Sangilen highland (Southeastern Tuva)]. AS USSR Proc., 1969, no 8, pp. 125-132. (In Russ.). 
4. Buslaeva E.Yu., Novgorodova M.I. Elementoorganicheskie soedineniya $v$ probleme migratsii rudnogo veshchestva [Organoelemental compounds in the study of ore matter migration]. Moscow, Nedra Publ., 1989. 151 p. (In Russ.).

5. Vedernikov P.G Rudnoe pole. Teoreticheskie i prakticheskie voprosy izucheniya [Ore field. Theory and practice of study]. Vladivostok, 1989. 111 p. (In Russ.).

6. Galimov E.M. Geokhimiya stabil'nykh izotopov ugleroda [Geochemistry of stable carbon isotopes]. Moscow, Nedra Publ., 1968. 222 p. (In Russ.).

7. Kamenskiy I.L., Lobkov V.A., Prasolov E.M., et al. [Helium and methane in the upper mantle of the Earth's crust occurring in the Kamchatka gases]. Tezisy dokl. V Vsesoyuz. simp. po geokhimii stabil'nykh izotopov [Report theses of the $5^{\text {th }}$ All-Union Symposium for Geochemistry of Stable Isotopes]. Moscow, 1974, pp. 148-149. (In Russ.).

8. Ermolaev N.P., Sozinov N.A. Stratiformnoe rudoobrazovanie $v$ chernykh slantsakh [Stratiform ore formation in black shales]. Moscow, Nauka Publ., 1986. 173 p. (In Russ.).

9. Shepel A.B., Gavrilenko M.E., Lepilin V.P., Belonozhko E.A. [Gold-bearing syntectonic metasomatites - ores of large-volume non-traditional gold fields]. Geologiya i minerageniya Sibiri - Geology and Minerageny of Siberia, Novosibirsk, SNIIGGiMS Publ., 2010, pp. 45-56. (In Russ.).

10. Shepel A.B., Golyshev S.I., Padalko N.L., et al. [Isotope research of carbon and oxygen of gold-ore shows in the Fedorovsko-Magyzy-Kaltasskaya zone]. XVIII simpozium po geokhimii izotopov imeni akademika A.P.Vinogradova: Tez. dokladov [The $18^{\text {th }}$ Academician A.P. Vinogradov Symposium for Geochemistry of Isotope: Theses of Reports]. Moscow, 2007, pp. 289290. (In Russ.).

11. Interpretatsiya geokhimicheskikh dannykh: Uchebnoe posobie [Geochemical data interpretation: A study guide]. Edited by E.V. Sklyarov. Moscow, Intermet Engineering Publ., 2001. 287 p. (In Russ.).

12. Karaganov V.V. [Performance of the Public Geological Service in 2001 and priorities of the Ministry of Natural Resources of Russia in development of the mineral resource base of Russia and its continental shelf in 2002]. Mineralnye resursy Rossii. Ekonomika i upravlenie - Mineral Resources of Russia. Economics and Management, 2002, no. 1-2, pp. 4-11. (In Russ.).

13. Konyshev V.O., Sevastyanov E.V., Vlasov G.N. [The Fedorovskoe-1 field and specifics of exploration of targets with large separation of gold form ores (Kuznetsk Alatau)]. Geologiya i mineral'nye resursy Tsentral'noy Sibiri - Geology and Mineral Resources of Central Siberia, Krasnoyarsk, 2003, pp. 146-156. (In Russ.).

14. Konyshev V.O. [The Fedorovsko-Kedrovskoe gold-ore field: The lithostratigraphic controls on gold content]. Otechestvennaya geologiya - National Geology, 2006, no. 2, pp. 13-20. (In Russ.).
15. Voytkevich G.V., Miroshnikov A.E., Povarennykh A.S., Prokhorov V.G. Kratkiy spravochnik po geokhimii [Brief guide for geochemistry]. Moscow, Nedra Publ., 1970. 277 p. (In Russ.).

16. Letnikov F.A Avtonomnye flyuidnye sistemy kontinental'noy zemnoy kory [Independent fluid systems of the continental crust]. Far East Branch of the Russian Academy of Sciences, 2009, vol. 427, no. 6, pp. 810-813. (In Russ.).

17. Martynov K.V. [Carbonaceous beresite-listvenite parageneses in low-sulfide fields of the Middle Urals]. Geologiya rudnykh mestorozhdeniy - Geology of Ore Felds, 1992, vol. 31, no. 5, pp. 46-56. (In Russ.).

18. Metasomatizm i metasomaticheskie porody [Metasomatism and metasomatic rocks]. V.A.Zharikov, V.L.Rusinov eds. Moscow, Nauchny Mir Publ., 1998. 492 p. (In Russ.).

19. Letnikov F.A., Savelyev V.B., Gorevanov D.E., Khalilov V.A. [Metamorphism and metasomathosis in zones of deep faulting of continental lithosphere]. Geotektonika-Geotectonics, 1996, no. 5, pp. 15-26. (In Russ.).

20. Shepel A.B., Gavrilenko M.E., Lepilin V.P., Belonozhko E.A. [Prospects of search for large-volume non-traditional gold-ore fields in the western part of the Altai-Sayan folded region]. Geologiya i minerageniya Sibiri - Geology and Minerageny of Siberia, Novosibirsk, SNIIGGiMS Publ., 2010, pp. 33-45. (In Russ.).

21. Skhemy mezhregional'noy korrelyatsii magmaticheskikh i metamorficheskikh kompleksov AltaeSayanskoy skladchatoy oblasti i Eniseyskogo kryazha [Schemes of interregional correlation of magmatic and metamorphic complexes of the Altai-Sayan folded region and the Yenisei ridge]. Edited by V.L.Khomichev Novosibirsk, SNIIGGiMS Publ., 2002. 178 p. (In Russ.).

22. Talantsev A.S. Geotermobarometriya po dolomit-kal'tsitovym paragenezisam [Geothermobarometry on dolomitic-calcitic parageneses]. Moscow, Nauka Publ., 1981. 136 p. (In Russ.).

23. Tugarinov A.I. Obshchaya geokhimiya [General geochemistry]. Moscow, Atomizdat Publ., 1973. 288 p. (In Russ.).

24. Shepel A.B., Gavrilenko M.E. [Gold prospects and exploration for large-volume fields of nontraditional gold in the pre-Cambrian successions of the western part of the Altai-Sayan folded region]. Zoloto Sibiri i Dal'nego Vostoka: geologiya, geokhimiya, tekhnologiya, ekonomika, ekologiya: Tez. Tret'ego Vserossiyskogo simp. s mezhdunarodnym uchastiem [Gold of Siberi and the Far East: Geology, geochemistry, technology, economics, ecology. Theses of the $3^{\text {rd }}$ All-Russia Symposium with international engagement]. Ulan-Ude, BNTs SB RAS Publ., 2004, pp. 245247. (In Russ.).

25. Shepel A.B., Gavrilenko M.E., Lepilin V.P. [Structural aspects of metamorphic complexes of the Altai-Sayan folded region]. Materialy regional'noy kon- 
ferentsii geologov Sibiri, Dal'nego Vostoka i SeveroVostoka Rossii [Proc. Regional Conference of Geologists of Siberia, Far East and Northeast of Russia], vol. 1. Tomsk, 2000, pp. 90-92. (In Russ.).

26. Shcheglov A.D., Govorov I.N. Nelineynaya metallogeniya i glubiny Zemli [Non-linear metallogeny and deep subsurface of the Earth]. Moscow, Nauka Publ., 1985. 325 p. (In Russ.).

27. Shcherbakov Yu.G. Geokhimiya zolotorudnykh mestorozhdeniy v Kuznetskom Alatau i Gornoy Shorii [Geochemistry of gold-ore fields in Kuznetsk Alatau and
Mountain Shoria]. Novosibirsk, Nauka Publ., 1974. 78 p. (In Russ.).

28. Bottinga Y. Calculated fractionation factor for carbon and hydrogen isotope exchange in the system calcite - carbon dioxide - graphite - aethane - hidrogen - water. Geochim. et Cosmochim. Acta, 1969, vol. 33, no. 1, p. 49.

29. Valley J., O'Neil J.R. ${ }^{12} \mathrm{C} /{ }^{13} \mathrm{C}$ exchange between calcite and graphite a possible thermometer in Grenvile marble. Geochim. et Cosmochim. Acta, 1981, vol. 15, no. 5, pp. 411-419.

(C) А. Б. Шепель, М. Е. Гавриленко, 2016

ШЕПЕЛЬ Альберт Борисович, Сибирский научно-исследовательский институт геологии, геофизики и минерального сырья (СНИИГГиМС), Новосибирск, вед. науч. сотр., к.г.-м.н. E-mail: shepel@sniiggims.ru

ГАВРИЛЕНкО Маргарита Евгеньевна, Сибирский научно-исследовательский институт геологии, геофизики и минерального сырья (СНИИГГиМС), Новосибирск, ст. науч. сотр. E-mail: shepel@sniiggims.ru

SHEPEL Albert, PhD, Siberian Research Institute of Geology, Geophysics and Mineral Resources (SNIIGGiMS), Novosibirsk, Russia. E-mail shepel@sniiggims.ru GAVRILENKO Margarita, Siberian Research Institute of Geology, Geophysics and Mineral Resources (SNIIGGiMS), Novosibirsk, Russia. E-mail shepel@ sniiggims.ru

\section{Университет МЕГАТРЕНД (Бепград, Республика Сербия)}

проводит 5-й Международный симпозиум по менеджменту природных ресурсов 25-26 июня 2016 г.

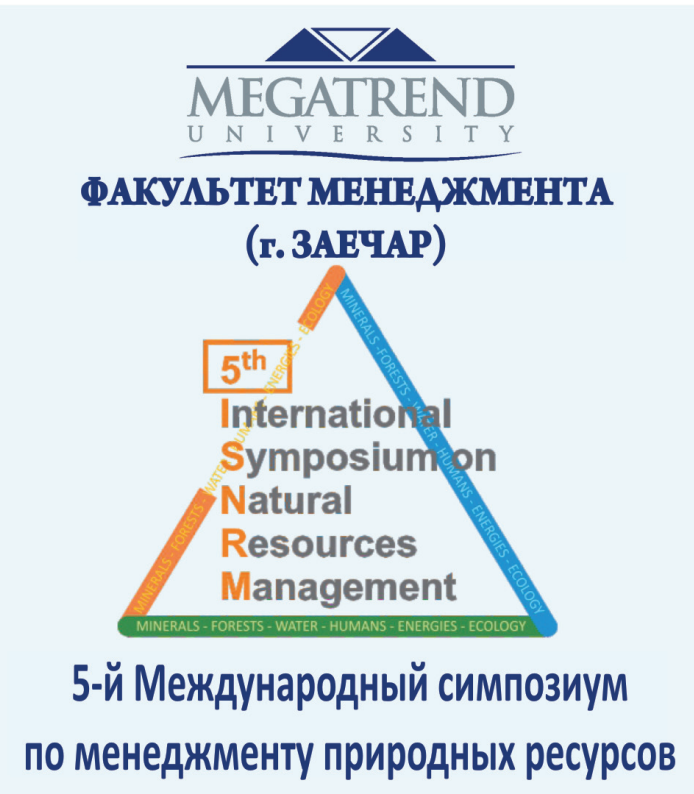

www.fmz.edu.rs

simpozijum@fmz.edu.rs

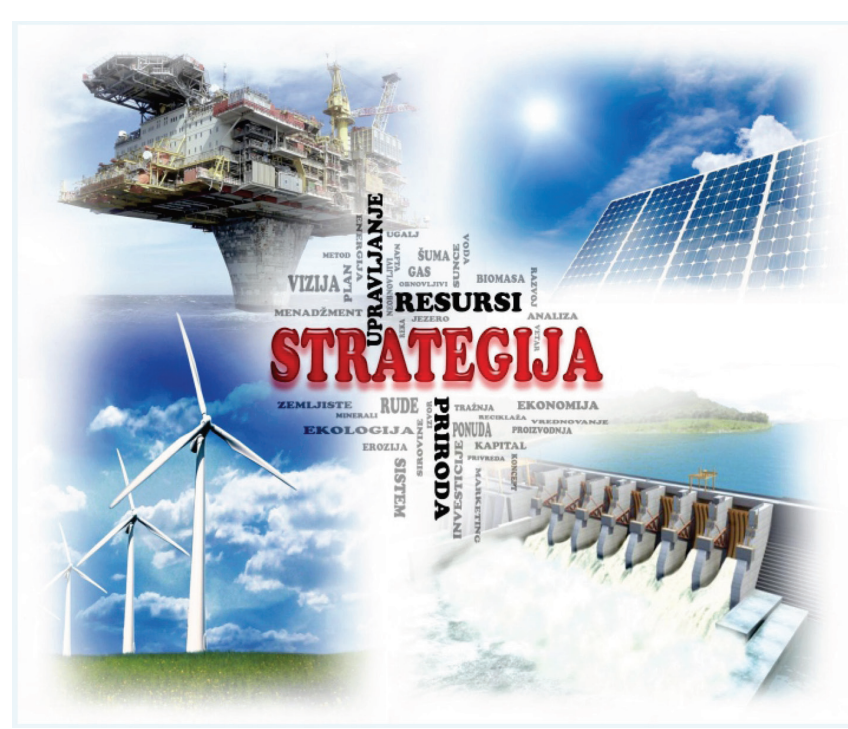

